\title{
Migrations and Metropolises: Photographic Views
}

Migrations et métropoles : visées photographiques

Migraciones y metrópolis: miras fotográficas

Anne Raulin, Sylvaine Conord, William Berthomière, Ines Ebilitigué and Alexa Färber

Translator. Juliette Rogers and Gary White

\section{(2) OpenEdition}

12 Journals

\section{Electronic version}

URL: https://journals.openedition.org/remi/10345

DOI: 10.4000/remi.10345

ISSN: $1777-5418$

This article is a translation of:

Migrations et métropoles : visées photographiques - URL : https://journals.openedition.org/remi/8188 [fr]

Publisher

Université de Poitiers

Printed version

Date of publication: 1 December 2016

ISBN: 979-10-90426-29-0

ISSN: 0765-0752

\section{Electronic reference}

Anne Raulin, Sylvaine Conord, William Berthomière, Ines Ebilitigué and Alexa Färber, "Migrations and Metropolises: Photographic Views", Revue européenne des migrations internationales [Online], vol. 32 n`3 et 4 | 2016, Online since 01 December 2018, connection on 14 April 2022. URL: http:// journals.openedition.org/remi/10345 ; DOI: https://doi.org/10.4000/remi.10345

This text was automatically generated on 14 April 2022.

(c) Université de Poitiers 


\title{
Migrations and Metropolises: Photographic Views
}

\author{
Migrations et métropoles : visées photographiques \\ Migraciones y metrópolis: miras fotográficas
}

Anne Raulin, Sylvaine Conord, William Berthomière, Ines Ebilitigué and Alexa Färber

Translation : Juliette Rogers and Gary White

\section{Introduction}

The connections between migration, metropolitan cities, and photography were not born yesterday. In fact, they go back to the spread of photography as a way of providing an account of reality and supplying proof. A concern with bearing witness to the living conditions of migrants in the nineteenth century is associated with the name of Jacob A. Riis (1849-1914), especially in the United States, which was a major destination country at the time. An immigrant from Denmark himself, Riis ceaselessly decried the insalubrity of the lodgings to which new arrivals were consigned in major cities (New York in this case), rental properties called tenements. His book How the Other Half Lives: Studies among the Tenements of New York, published in 1890, included numerous photographs that helped to convince public opinion of the necessity of significant social reforms.

Lewis Hine was particularly sensitive to migrant populations. His first photographs were devoted to immigrants arriving through Ellis Island in the early twentieth century, and he later turned to denouncing the exploitation of children, who worked in great number at home and in the mines and textile factories of the east coast. His Men at Work (1932) was an homage to the workers that built the Empire State Building, but Hine most generally pursued "social photography." His sensitivity and his conviction that photography could be used to improve knowledge and transform society undoubtedly owe much to his factory work experience and his intellectual training in sociology at the University of Chicago with Louis Wirth, and then at New York 
University. With Hine, photography became a veritable form of institutional imaging destined to inspire and justify the actions of public authorities (Maresca 1996: 75). The Great Depression following the 1929 crash and its terrible consequences on the living conditions of urban and rural populations alike led the Roosevelt administration to create massive social programs in widely differing regions of the United States, calling on photography. The FSA (Farm Security Administration) enabled the creation of many bodies of documentary work that have now become classics, by the likes of Walker Evans (Alabama, 1936), Dorothea Lange (California, 1936), and Lewis W. Hine. Although we tend to regard these images with an aesthetic eye today, we must not forget that they were produced with utilitarian aims, as governmental propaganda to increase support for social assistance (Tennessee, 1938).

3 If we speak of a New York school of photography, it is because its photographers took the metropolitan city and its inhabitants old and new as object, and not because they shared a particular style. Their concerns were aesthetic, moral, social, and in some cases explicitly political, as attests the New York Photo League ${ }^{1}$, whose radical and anticapitalist orientations became apparent. The collective produced works such as Harlem Document, a photographic essay on Harlem intended to give a realistic image of the working class in the progressive press (some images were published in a magazine 1940, but it was not published as a book until 1981),

Despite its political dimension and tensions arising from McCarthyism (which would put the NY Photo League on the blacklist of pro-communist organizations, leading to its dissolution in 1951), social photography and sociology grew connections during this period, although, as Maresca and Meyer remind us, most of the images found in social science publications were only for illustrative value and "were not deeply rooted in theoretical arguments" (2013) The history of the New York Photo League nonetheless leads us to think that any reservations about political aspects came mainly from academics, since League members and heirs (such as Diane Arbus and Robert Frank) always clearly stated the objectives of the photographic practices they promoted.

Indirectly, the position of Sid Grossman ${ }^{2}$ renews a debate that even today leaves lingering doubts as to the intrinsic analytical value of photographs, and especially those produced as part of urban research. This debate is focused on researchers' presumed difficulties in abandoning an aestheticizing or even artistic approach, and secondarily raises methodological questions by challenging the random character of certain choices in shots and the scientific dimension of shots taken while meandering in and around the city. These reservations are embodied in the figure of the flaneur and the infatuation that can develop for "the flaneur's availability to meet the other, to let himself encounter the signified that urban reality produces in abundance" (Nuvalotti, 2009: 70). In her response to Moore (2008), speaking of the relationship that developed between Chicago-school sociology and the NY Photo League, Goldstein (2008) highlighted the importance of this figure and Walter Benjamin as a reference since the publication of Paris, capitale du XIXe siècle (1989; published in English as The Arcades Project, 2002).

"The figure of the flaneur has proved so compelling to us over the past decades because he combines in himself the social scientist and the artist; that is, he transforms what he observes into art. Who among us would not want to be an artist as well as a (instead of?) a social scientist?" (Goldstein, 2008: 121-124).

Street photography would quickly raise more specific questions, however, like the relationship between the subject and object of the gaze ("What is the relatedness of 
seer and seen?" wondered Max Kozloff [quoted in Moore, 2008) and the photographer's relationship with the people in his or her images. Given the technical conditions for taking a shot, poses used to be necessary and required not only the subject's agreement, but also their active participation. Therefore, what kind of reciprocity to establish with these street performance artists? Moreover, what does the photographer's gaze provide for us to see, and how much of it is his or her interpretation? What social or ethnic invisibility are you entitled to denounce, or to make legible, and how to make visible without stigmatizing?

These questions, which are revived regularly, have in no way held back the economy of this relationship dating to the late nineteenth century. Photography has established itself in studies aiming to document societal diversity and developments, from Jacob Riis's work to that of John Jr. Collier, Howard S. Becker and Douglas Harper, not to mention the uses of photography in Europe, particularly by Maurice Halbwachs, who photographed the tenements of the Cité Jeanne-d'Arc in Paris's 13th arrondissement in 1908 (Topalov, 1997). This dynamic is even more remarkable because, in over a century of dialogue and encounters, it has led to publications by photographers trained in the social sciences as well as sociologists and anthropologists practicing illustrative photography, collaborating between these two professional worlds. The emergence of the syncretic figure of the researcher-photographer is a full-fledged contribution to the strengthening of the conceptual basis of street photography and the development of the ability to capture a sense of street smarts.

The thirtieth anniversary of the Revue Européenne des Migrations Internationales seemed like a fine occasion for a special issue assessing how this association between photography and social sciences has manifested itself and sought to render the presence of migrants in major metropolitan cities visible in recent decades. What have researchers and photographers sought to reveal? What relationships have been hatched between researchers and objects of study? How has the frame shifted? And this both literally, since today's camera is digital and can be easily used by everyone (after revolutionary technological changes, photography is now accessible to all) and figuratively, since, in addition to the desire for reform, photography now seems to be used as a tool for research and enhancing migrants' sense of self in cosmopolitan cities, which have a continually evolving relationship to the image.

9 What follows are seven contributions from authors working in the urban field that have crossed ethnographic writing with photographs in a range of periods and settings, each with their own practices for working with images, spanning established professionalism, enlightened amateurism, and artistic expressionism.

They explore how the landscapes of four major European cities - Paris (through three field sites), London, Berlin, and Lisbon - plus Tel Aviv in Israel are constantly being reshaped by migratory and diasporic flows. Photography provides an account of ways in which minorities are visible that may be more or less obvious to city-dwellers, who may be drawn to or fascinated by what they perceive, and unsettled and troubled by it.

11 These contributions reveal a discernable change in how photography can be included in urban studies and urban development. They go from participation in building an intimate collective memory - backtracking the childhoods of women that experienced complex diasporic paths, approached through public places in Paris and the women's pilgrimages (Sylvaine Conord] - to participation in a historical dynamic manifesting 
the presence of a cosmopolitan population, explored in a Lisbon neighborhood undergoing renewal in a prelude to the process of social mixing (Hélène Veiga Gomes).

The photographic project may latch on to a significant urban object, such as shisha pipes, which have become a symbol of a multicultural ideology in the post-socialist and post-Soviet setting of Berlin (Alexa Färber), and protective shrines in businesses of the Chinese diaspora in Paris, an extraordinary assemblage of the religious and the economic (Anne Raulin). In these instances the objects lend themselves to photography, but the practices that go with them (smoking, conducting business) less so.

The re-creation of African commercial worlds explicitly addressing immigrant clienteles (while also serving a broader public) interests both Ines Ebilitigué in Paris and Guillaume Ma Mung in London's Afro-Caribbean market space. Photographic documentation probes how people experience being far from their country and the formation of signs in the city indicating a compensation for this emptiness.

William Berthomière resolutely situates his work in the flaneur's perspective and the perception of an environment in constant change, thus echoing the notion of "lieumouvement" (place-movement) developed by Joseph (2006). Various waves of migration engrave themselves in the walls of Tel Aviv, in more or less formal styles. Photography in this case takes the place of "floating observation" (Pétonnet, 1982) and follows the traces of transformation on the skin of the city walls.

Anne Raulin, William Berthomière, Sylvaine Conord

\section{Photography and the Social Sciences in the Study of Collective Community Memory. Contribution by Sylvaine Conord}

From its conception to its perception, the photographic image is at the centre of a complex system of individual and social realities. As Terrenoire (1985: 514), one of the first researchers in France to have published an epistemological study on the photographic image, points out: "in the image, as in discourse, recipient, message and emitter are co-present. The image therefore functions as the matrix of a social relationship and, in fact, falls entirely within the realm of the social sciences." Yet photography has long been criticised and rejected from the field of scientific research due to its subjective or aesthetic character, as pointed out by Garrigues (1991), Piette (1992) and Maresca (1996). Nonetheless, the place it has taken in the history of our society, the role it plays in the transmission of collective and individual memory, the various functions it fulfils as a way of representing the self and the Other, and, not least, the pioneering works by American scholars (Mead and Bateson, 1942; Collier, 1967; Becker, 1981 and 2002) have created a favourable context for the development of its practice in anthropology and sociology from the 1990s to the present.

16 The fact that the image does not have the same status as other materials justifies the questioning of this difference (Péquignot, 2008). Indeed, Becker (1981 and 2002), a major figure in contemporary sociology, has argued since the 1970s that there can be a better dialogue between photography and sociology, thus reflecting a renewal of scientific methods in the exploration of society and the importance of research findings (Maresca and Meyer, 2013: 19). To prove his point, Becker took the example of a visual 
work that could be integrated into the social sciences, namely book by Berger and Mohr (1982) on immigrant communities working in Europe, which is illustrated with numerous black and white photographs (Becker, 2002). It is striking that one finds the same content and framing in these images as in contemporary photographs representing the living conditions of migrants: portraits, crowds of women pushing against barriers, a man carrying heavy suitcases in a train station corridor, a guard examining a migrant's papers before letting him pass through a gate, men sitting hunched over a table laden with empty beer bottles. In this book, each image is specific, and they show real people as Becker (2002) points out: migrants leaving Turkey, Greece or Yugoslavia, travelling in large numbers to the train stations of Germany or France. In this book, the images attest to this reality even if the captions do not enable us to recognise each individual represented by his/her name or his/her history. The relationship between text and image is therefore fundamental, all the more so if we wish to use photography as a research tool in sociology or anthropology. A further question worth asking is whether, in some cases, images can replace words. To put it more precisely, what is the value of the image in a scientific argument?

The photographic medium is at the same time reproduction, imprint and interpretation of reality. The analyses of Barthes (1980) emphasize the specificity of the photographic medium compared to other iconographic media. The indexing nature of the photographic image creates a special relationship between man and photography. Taking inspiration from Charles Sanders Peirce's theory of meaning ${ }^{3}$, Dubois describes photography as "proceeding from the index [...] i.e. a representation, by physical adjacency, of the sign with its referent" (Dubois, 1990: 40-41). Due to this quality, the photographic image becomes a true mode of knowledge, since it is always linked to a referent that becomes the object of research. It is then a matter of questioning the nature of this medium and understanding how it can interest the anthropologist or sociologist in studying social realities and the observation of the other. In a research situation, the representations in question are those of the photographing subject and those of the photographed subject. In this perspective, the introduction of the image and the practice of photography in all the relationships experienced between the researcher and his or her field of study, allow for different points of view come together.

18 A research project conducted from the late 1990s to the 2000s concerning the study of the practices and beliefs of Sephardic Jewish women of Tunisian origin (Conord, 2007b) illustrates how the researcher-photographer's long-term involvement in the field ${ }^{4}$ acquires a memorial value. These women left Tunis for France in the 1950s (Photo 1). I met them in the Parisian district of Belleville, at the Café La Vielleuse, located at the corner of the Rue de Belleville and the Boulevard de Belleville (Photo 2). They frequented the café daily, just as their mothers used to meet at a café on Place Khalaline in Tunis. Following a photographic study on the cafés of the Belleville district (Steiner and Conord, 2010) I was able to make contact with them while they were sitting on the inside terrace of the café, as was their daily custom. Most of them had not seen their country of origin for 35 years (Tapia and Simon, 1998). Originally from working-class backgrounds in the Hafsia district of Tunis, they expressed themselves in Arabic dialect ${ }^{5}$ and were very attached to their culture of origin whose rites and customs they perpetuated. Sometimes recognised as guardians of traditions, sometimes perceived as trivial because of their frequentation of Belleville cafés and the manner in which they expressed themselves, these retired women ${ }^{6}$ were the bearers of a page in 
the history of twentieth-century Tunisia, that of part of their working-class Tunisian Jewish community.

Photo 1: Gisèle and her husband in Tunis in the 1950s

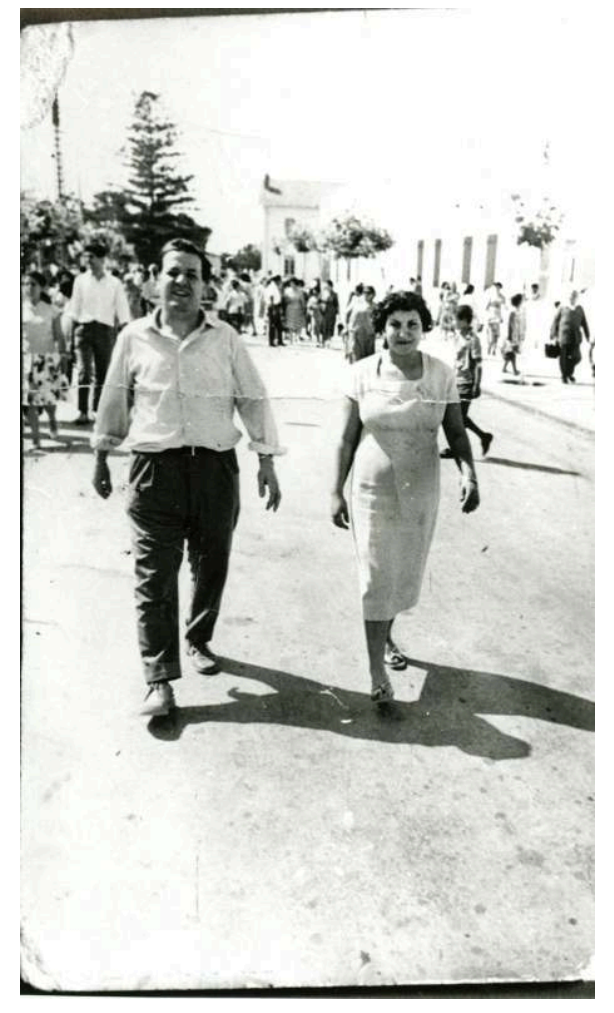

Source: Photograph taken from a family album.

Photo 2: Clients of Café La Vielleuse on Rue de Belleville

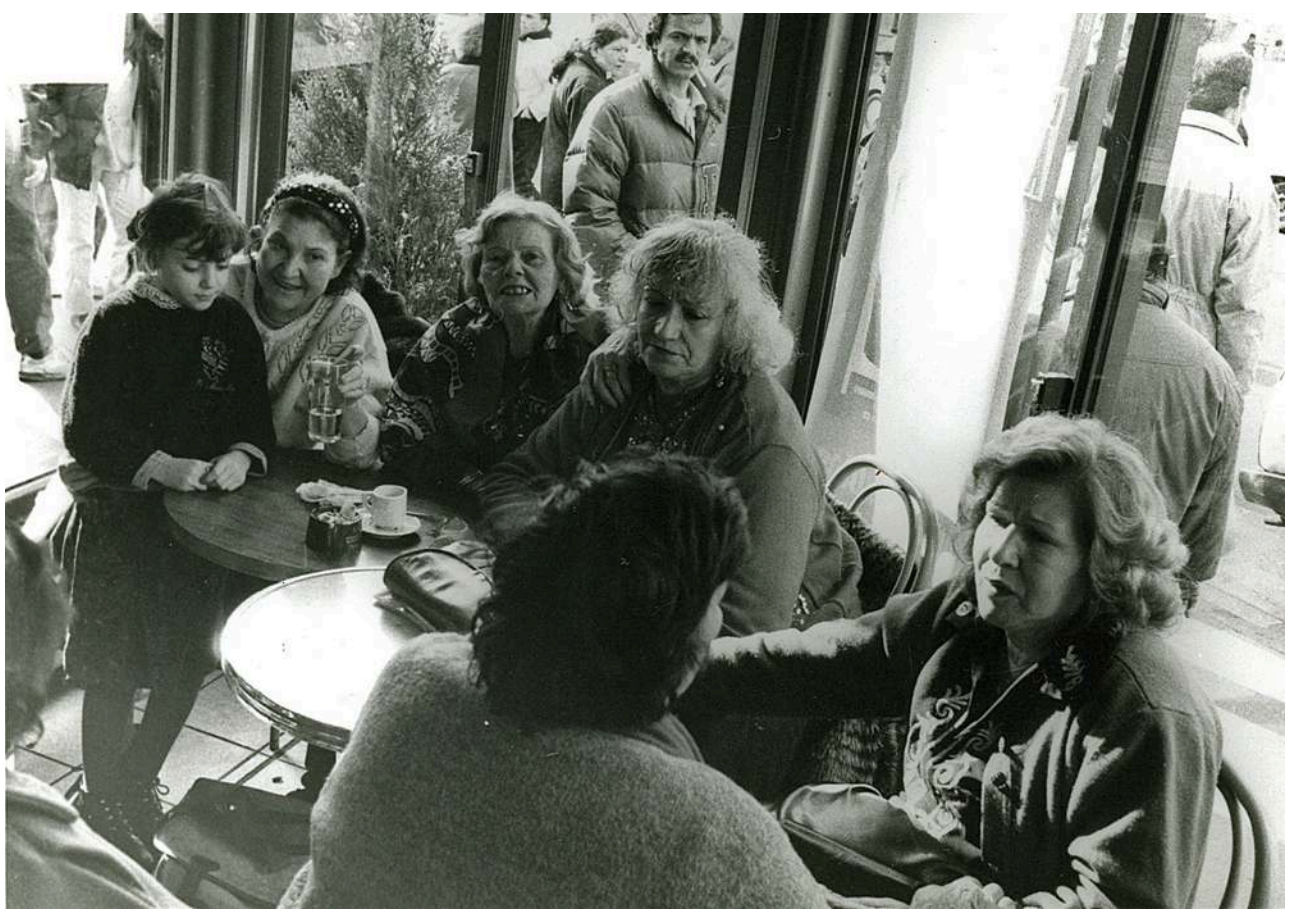

Credit: S. Conord, Paris, 1998 
19 build a memory. The memory of people who were forced to leave their country of origin, in this case Tunisia, is twofold: individual, interior or internal memory, made up of recollections attached to their personal history, and a collective social memory or historic memory (Halbwachs, 1997: 99). As such, photography functions as a testimony: it attests to the existence of a reality (Dubois, 1990: 48). It is not a transparent reflection of the realities it represents, but due to its complex nature and its multiple functions in social relations, for the anthropologist or sociologist it can become a relevant instrument of investigation and an object of memory.

several weeks of building confidence, these clients of the Café La Vielleuse considered me admitted to their circle thanks to my skills as a photographer. Before long they invited me to various religious (Photo 3) or secular (Photo 4) festivals and ceremonies to have me take pictures. My photographic practices not only earned me their satisfaction, they also became to form a visual archive, which would serve as a resource to both the photographed subjects (for photos intended to be placed in family albums) and to me personally within the framework of my research. Through the role of photographer that had been assigned to me, I found myself both invited in and standing on the outside, guided by what I was able to witness. For example, I had the opportunity to photograph a custom of rural origin rarely observed in France, related to the cutting of a fish (Photo 5) by a young couple a few days after their marriage. At the end of a family meal, a raw fish is brought to the two newlyweds and they are given two knives. The woman manages to cut up the fish, but the man struggles. The custom is that he can't do it because a piece of wood has been placed inside the fish to stop him. This scene symbolically expresses the supremacy of the woman in her home, an essentially female place in North Africa. 
Photo 3: Bar mitzvah, religious coming of age of a boy at thirteen

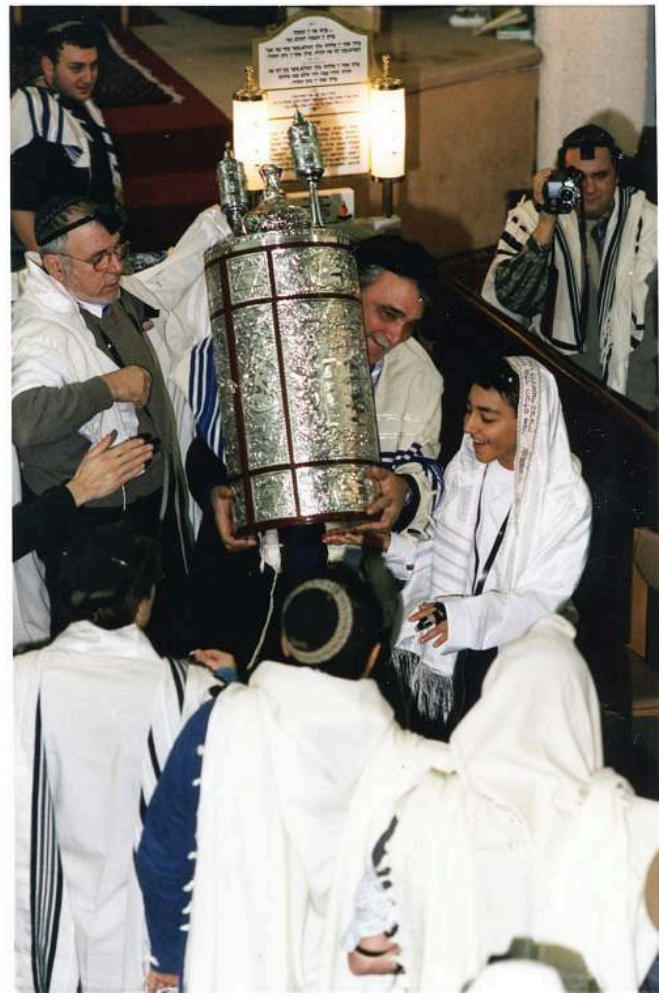

Credit: S. Conord, Paris, 1997

Photo 4: Rebaybia, monthly dances practised in Tunisia then organised in France. A musician playing the darbouka, another the Ghaita, and a percussionist with a bendir accompany a singer performing tunes that were famous in Tunis while the women dance

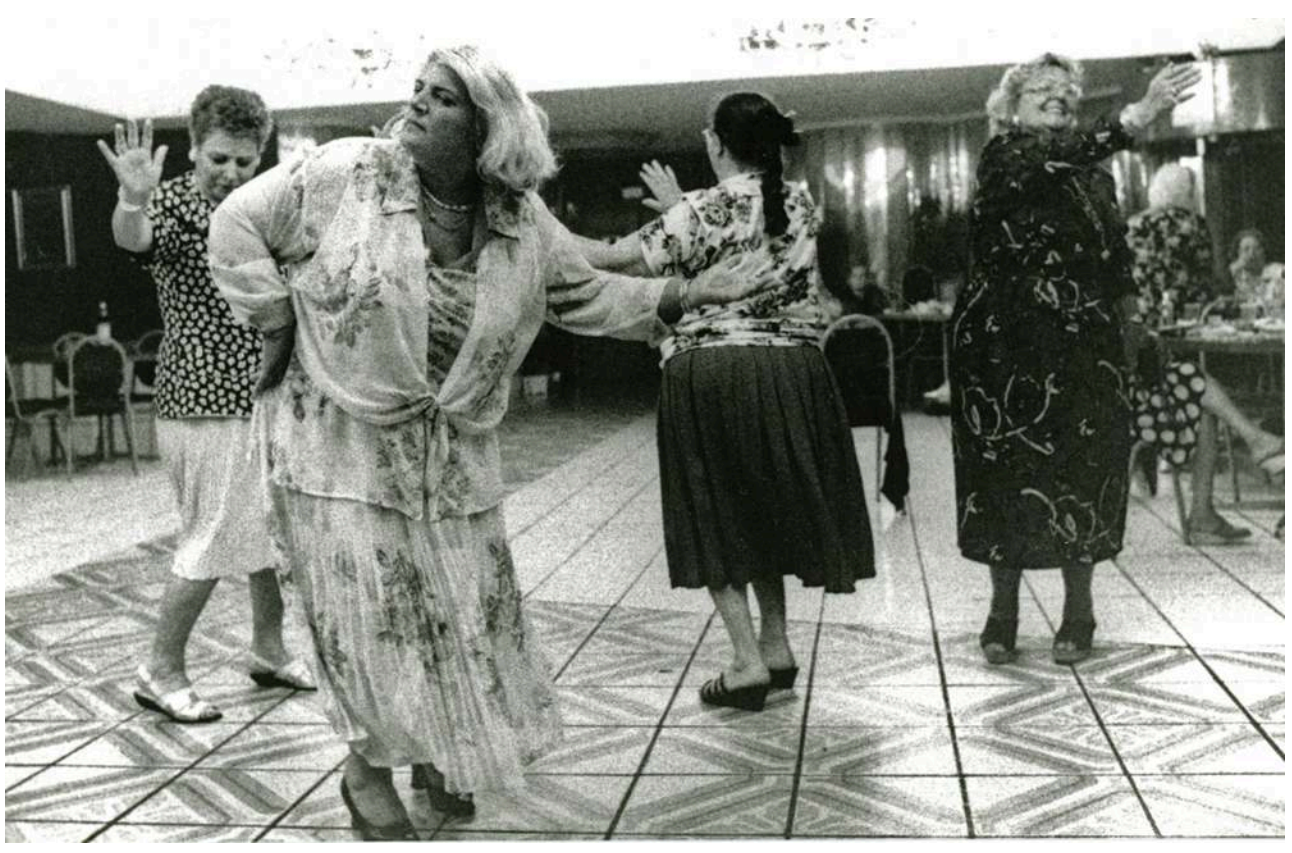

Credit: S. Conord, Paris, 1998. 
Photo 5: The cutting of the fish by two newlyweds

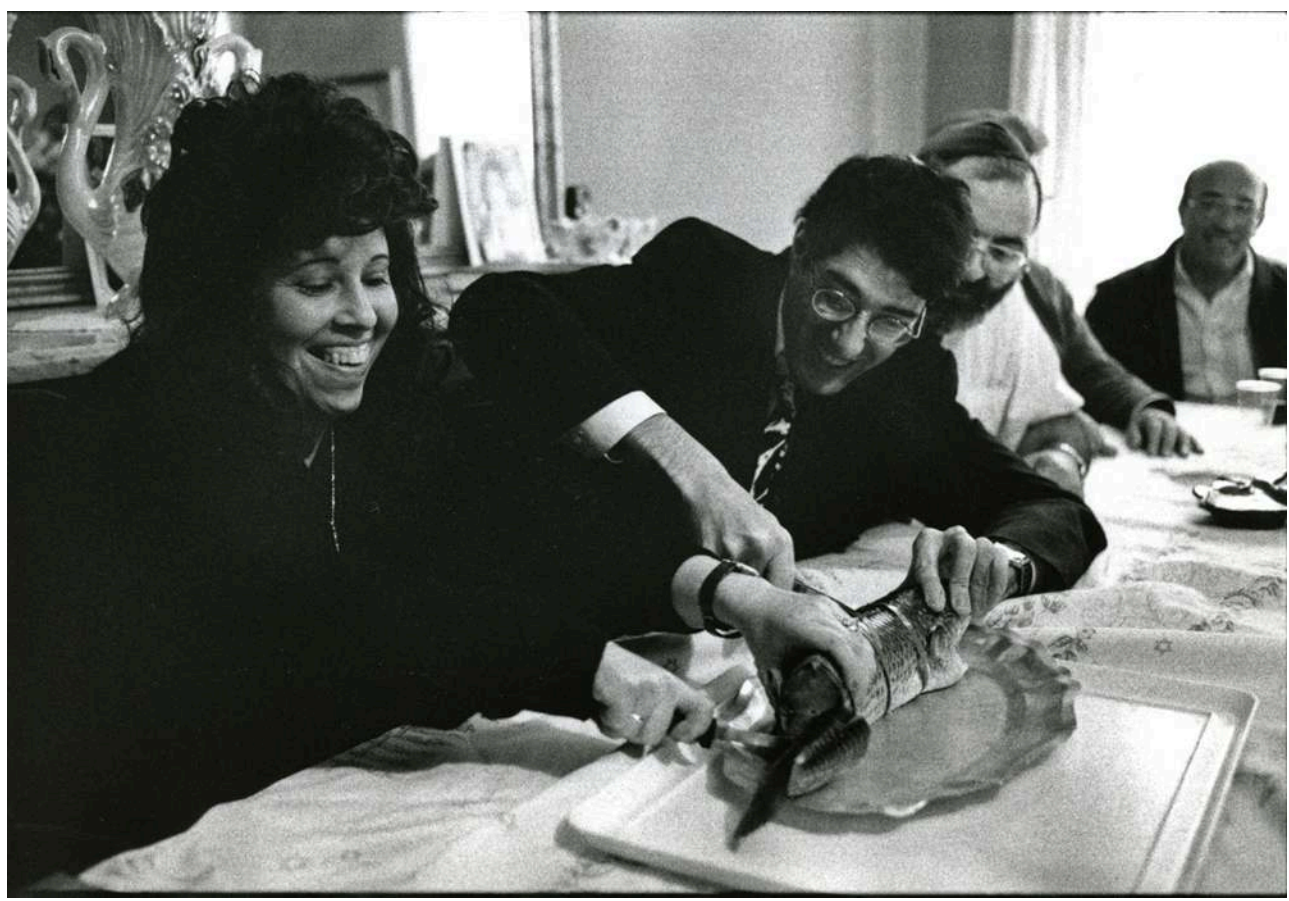

Credit: S. Conord, Paris, 1996.

21 Two highlights of this study were my participation in the annual Lag ba-Omer ${ }^{7}$ pilgrimage, the first year in Israel $^{8}$ and the following year in Tunisia ${ }^{9}$. The pilgrimage is generally considered a journey to places of religious worship. The general reason for this trip is the deep conviction that prayers and other religious practices are exceptionally effective in places connected with a saint or divinity. Tunisian Jewish women living in Paris essentially expect the pilgrimage to cure an evil or gain them a favour. Marta wants to make a prayer for the birth of a son for her daughter by lighting candles (Photo 6). The thirty-third day of Omer marks a very important feast day for these women, that of Rabbi Shimon Bar Yochai. The ceremonies that take place during the Hillula (feast to commemorate the death of a saint) attract many Sephardic and Ashkenazi Jewish pilgrims to Israel to visit the tomb of this revered rabbi, located on top of Mount Meron (Photo 7). A later moment of prayer is reserved for the Wailing Wall in Jerusalem (Photo 8). In both places, there is intense fervour, as there is in Tunisia at the El Ghriba synagogue on the island of Djerba (Photo 9) (Allali et al., 1997). Observing the pilgrimage helps to better understand the religious practices and reasons that motivate pilgrims to go to Djerba whereas they did not make the trip (considered expensive) when they lived in Tunis (Photo 10). 
Photo 6: Lighting candles during the Lag ba-Omer pilgrimage, Netanya

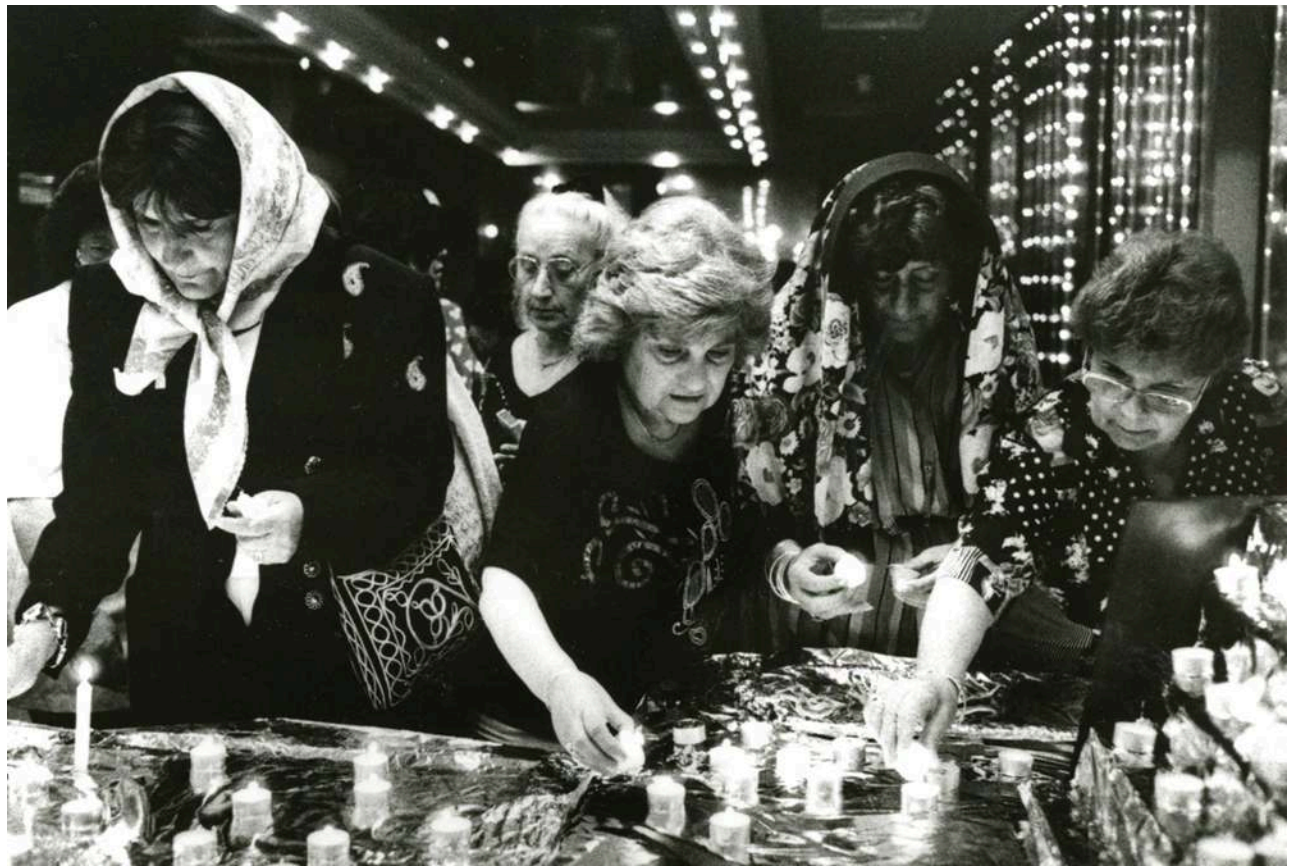

Credit: S. Conord, Israel, 1995

Photo 7: On top of Mount Meron, Lag ba-Omer pilgrimage

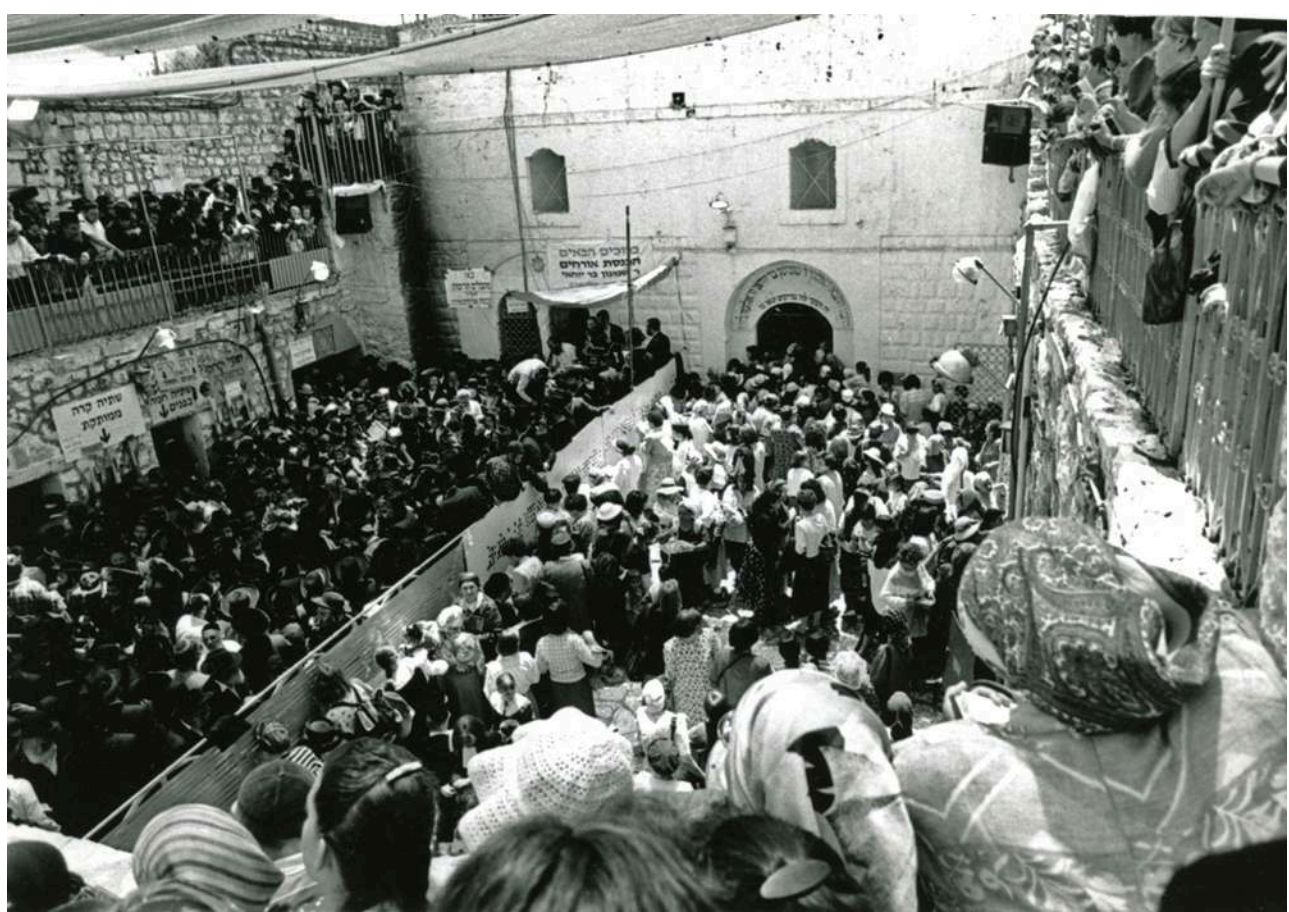

Credit: S. Conord, Israel, 1995 
Photo 8: The Wailing Wall, Jerusalem. We see Gisèle in the foreground to the right of the image depositing small papers on which she has written the prayers she wishes to see granted

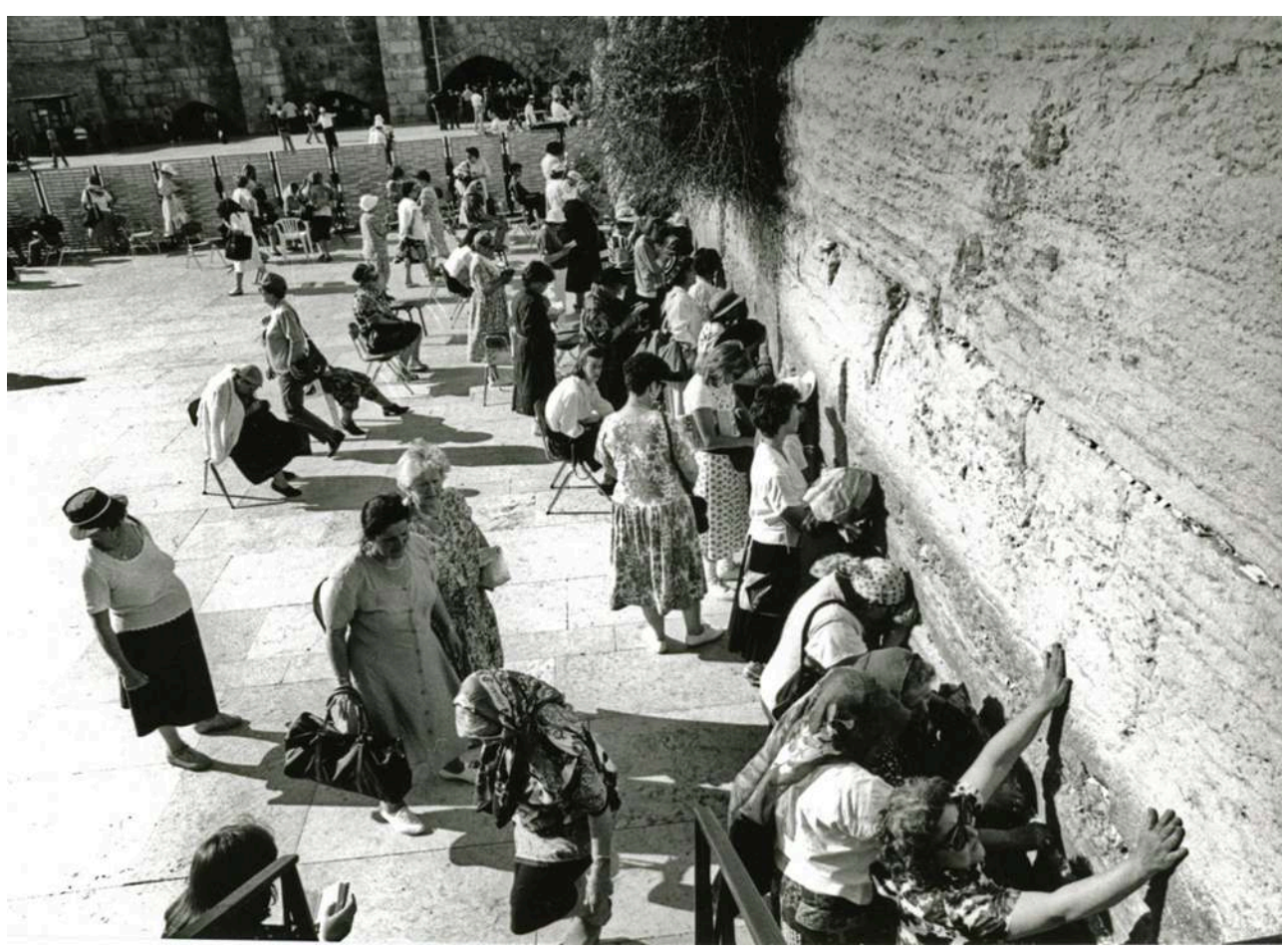

Credit: S. Conord, Israel, 1995

Photo 9: Inside the El Ghriba synagogue a pilgrim lights a candle while making a prayer, island of Djerba

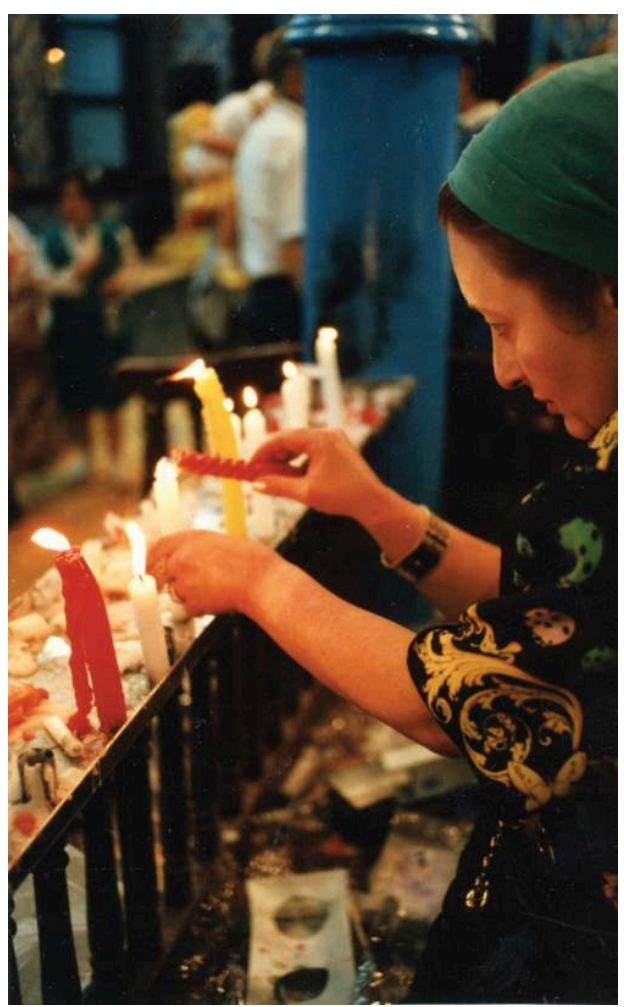

Credit: S. Conord, Tunisia, 1995

Revue européenne des migrations internationales, vol. 32 - n³ et 4 | 2016 
Photo 10: Procession from the EL Ghriba synagogue to the nearby village around a ritual object, the Menorah, covered with scarves that are touched and embraced, Djerba

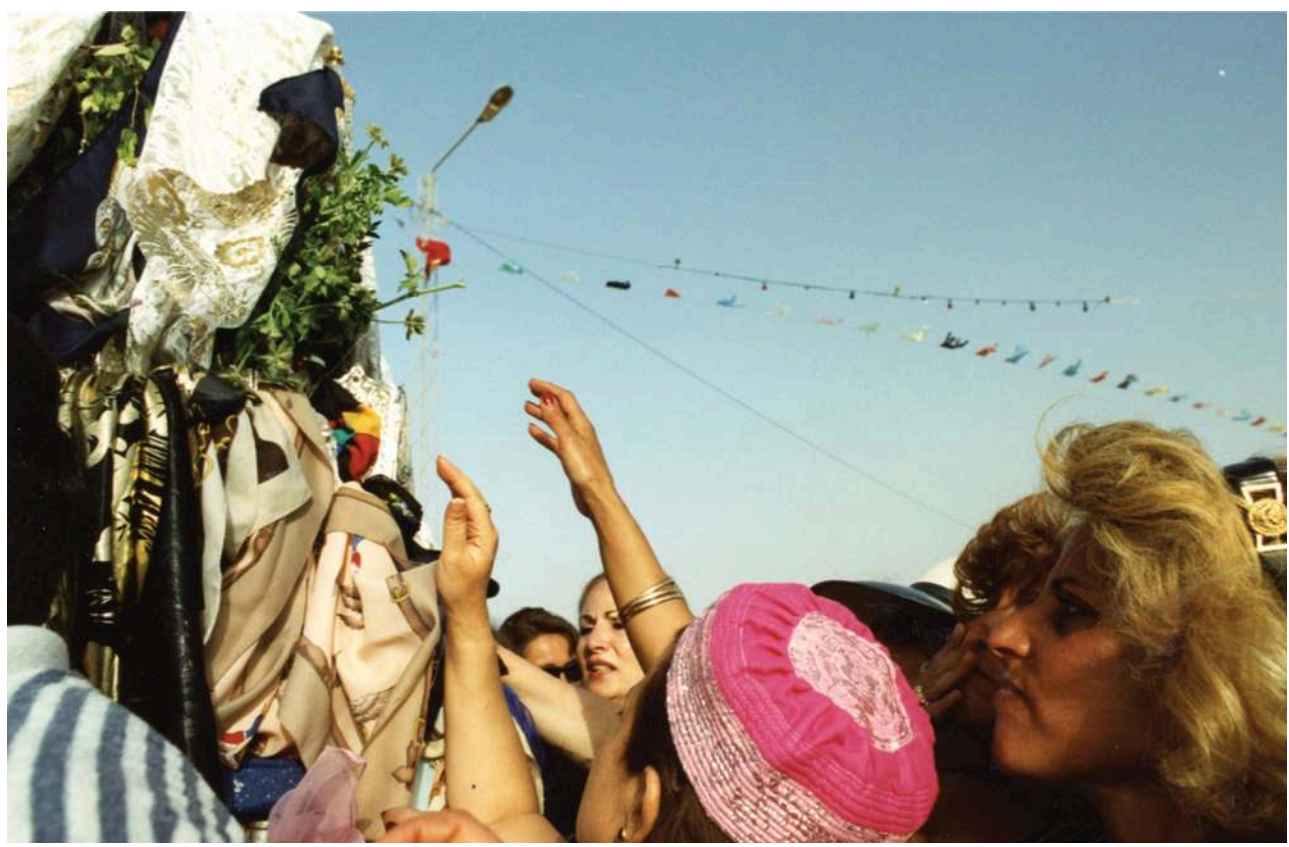

Credit: S. Conord, Tunisia, 1995.

Photography, whose specificity is to belong both to the present and the past, therefore plays an essential role in the study of individuals from an immigrant background, deeply attached to the memories of a bygone past, that of the youthful years they spent in their country of origin. While the attachment to place on the island of Djerba is weak and organised tourism very present (Conord, 2010), the fact remains nevertheless that returning to childhood locations creates strong emotions especially during a visit of the city of Tunis ${ }^{10}$. Numerous snapshots intended to show children, grandchildren born in France, the family home, a street or the grave of a loved one were then taken by pilgrims or asked of me. The pilgrimage was a pretext for this other, more personal journey. The excursion began with a visit to the Jewish cemetery, which was found in a rundown state in 1995 (Photo 11). In tears, women sought to find a loved one's grave by wandering along what was left of the paths. Then we headed to the Hafsia district where the majority of the women had spent their youth. They went from street to street looking for "their" home or that of their grandparents. When we found the places despite the changes in the neighbourhood, they asked me to take pictures of them in front of such and such a door or staircase. 


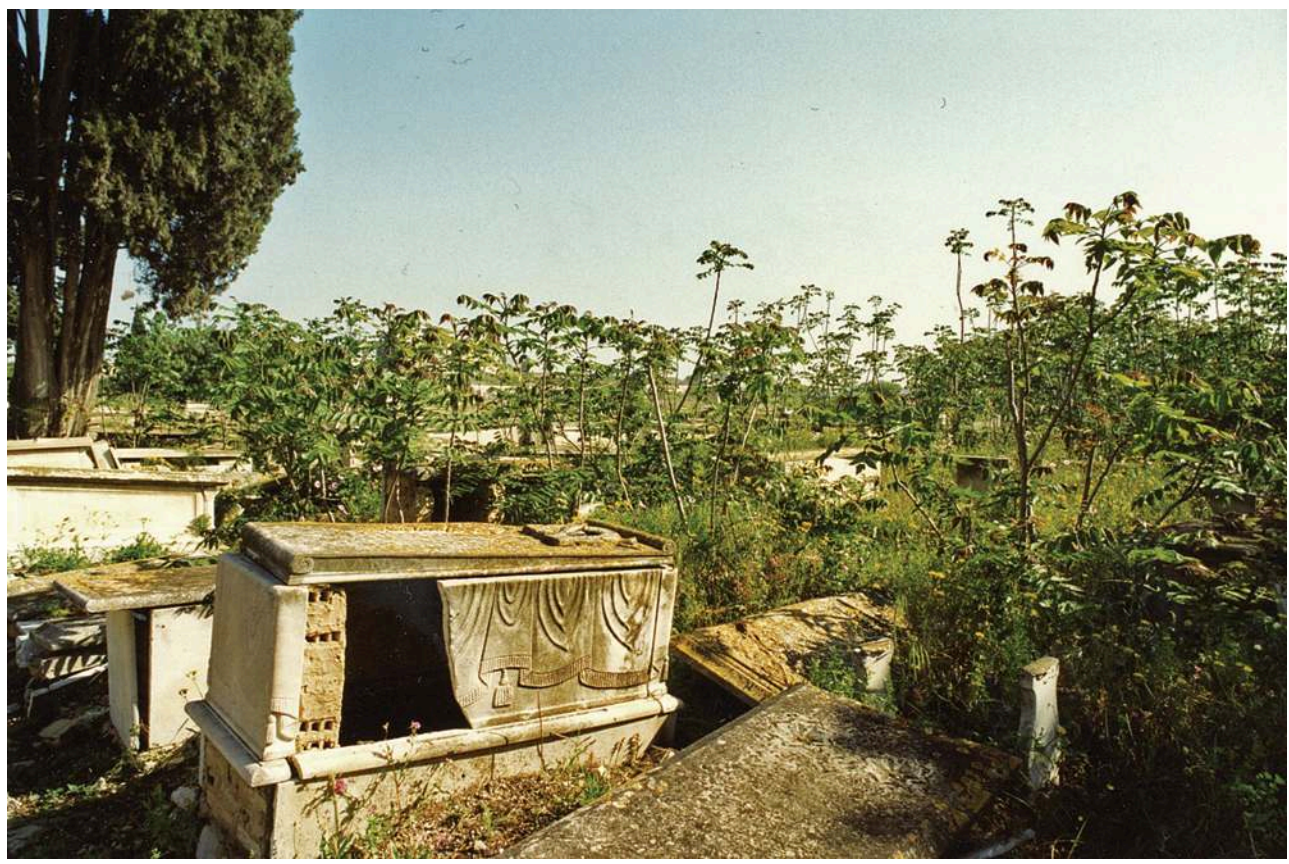

Credit: S. Conord, Tunisia, 1995

Photography is a trace. Soulages states that "every photo is that rebellious and dazzling image that enables us to question both the elsewhere and the here, past and present, being and becoming, fixity and flow, the continuous and the discontinuous, object and subject, form and material, sign and... image" (Soulages, 2005: 5). Photography, which has been described as a luminous imprint (Dubois, 1990), not only retains elements of personal and collective history, it also participates in the reflection on the relations between Self and this Other who is different and similar at the same time, on the relations between the researcher and the people encountered in the field ${ }^{11}$.

Years later, most of these women have passed away. They succeeded in sharing images from here and elsewhere, from Tunisia or Israel with their children and grandchildren, who sometimes accompanied them on pilgrimages. At the café, at a party or ceremony, before a ritual object or in the symbolic places of the pilgrimage, and also at their hotels, in buses, alone or next to their friends, smiling facing the camera and in colour, they transmitted to the researcher and to future generations a page of their history, that of women from Tunis, workers, canteen employees, seamstresses, living in France. The photographs taken and collected are part of a threefold memory process since it concerns the individual, the collective memory and that of the researcher who tries to transmit the memory of a community in the making.

\section{Shop Ethnographies: Photographing a Religious and Economic Assemblage. Contribution by Anne Raulin}

Photography was called upon in an entirely different context in Paris, during roughly the same period, with the observation of a novel migration that nonetheless had some points in common with that of Tunisian Jews. It was a consequence of the end of the Vietnam War and the country's independence and reunification under a communist 
government, which set off a massive exodus and the opening of Western countries to these refugees, who enjoyed exceptionally hospitable conditions at a time when borders were closed to economic migration. Some of these migrants were part of the Chinese commercial diaspora that had long been established in Southeast Asia, and many set their bags in France, leaving their distinctive mark most visibly in Paris' $13^{\text {th }}$ arrondissement, among others.

On first sight, the stereotype of Chinatown does not attract the anthropological gaze, because it seems to be urban folklore without any real depth, set up to serve the community's interest or for simple marketing purposes. Or it could be considered from the same perspective as Barth (1995), who deciphered this stereotypical character as a response to a situation of ethnic interdependence, imposing an easily identifiable register of expression in a culturally complex environment such as a metropolitan city. A step ahead of contemporary globalization, a Chinese presence has indeed been a significant spatial landmark in major cities worldwide since the nineteenth century. But such neighborhoods' characteristic style can hide a genuine anthropological depth. More than a simple story of décor, might the cultural staging of a commercial neighborhood serve the intention to contextualize the merchandise laid out there (Miller (1987) and Warnier (1994)? There is no doubt that an ethnic setting adds symbolic value to goods, operating as a site conferring authenticity to the products sold there. "Minority centralities" (Raulin 2000), which contribute to "diasporic public spheres" (Appadurai 2015), are indeed identified through the commercial scenery that is the fundamental register of this ethnic visibility and without which this kind of commercial circulation would have no particular social basis: it thus sets itself apart from anonymous and undifferentiated distribution.

If "the shopkeeper ethnically identifies his clientele," (Ma Mung 2006: 89), the clientele ethnically identifies the shopkeeper in return. But do they have access to all the elements of the décor that compose these scenes? In these recreated worlds, other, more intimate and fundamental functions may remain closed to autochthonous customers and Westerners in general. This is because this décor is more than simple exoticism; it has meanings and sense to the business itself. In the case of Asian businesses we will see here, it includes a combination of economic and religious concerns that is new to Western cities. The merchants are not chased from the temple in this instance - it is the temple that finds its niche in each business. In other words, commercial activities occur under the protection of deeply personalized deities, a pantheon of holy figures and votive writings that stimulate the piety of the owners. These places of business are a remarkably fertile and lively stage for observing the phenomenon signaled by de Certeau, that "there is no place that is not haunted by many different spirits hidden there in silence, spirits one can 'invoke' or not" (1988: 108). How to document this phenomenon other than photographing it, by finding many shrines for the protection of a business and their locations, by decoding their iconography, by attesting to the everyday attentions of which they are the object? The photographic perspective here is to highlight the intermingling of shrines and professional furnishings - over the microwave, near a scale (photo 12), under the passthrough of a restaurant (photo 13), or between the coat racks (photo 14) -without breaking the continuity between commercial and ritual activity.

Shrines to the god of the land, Tu-Di Gong, are to protect the business's prosperity and are always placed on the ground. A deity's appearances vary depending on whether he 
or she is represented in scriptural, pictorial, or statuary form, and the attentions he or she is given.

Photo 12: Shrine to the god of the land, produce shop

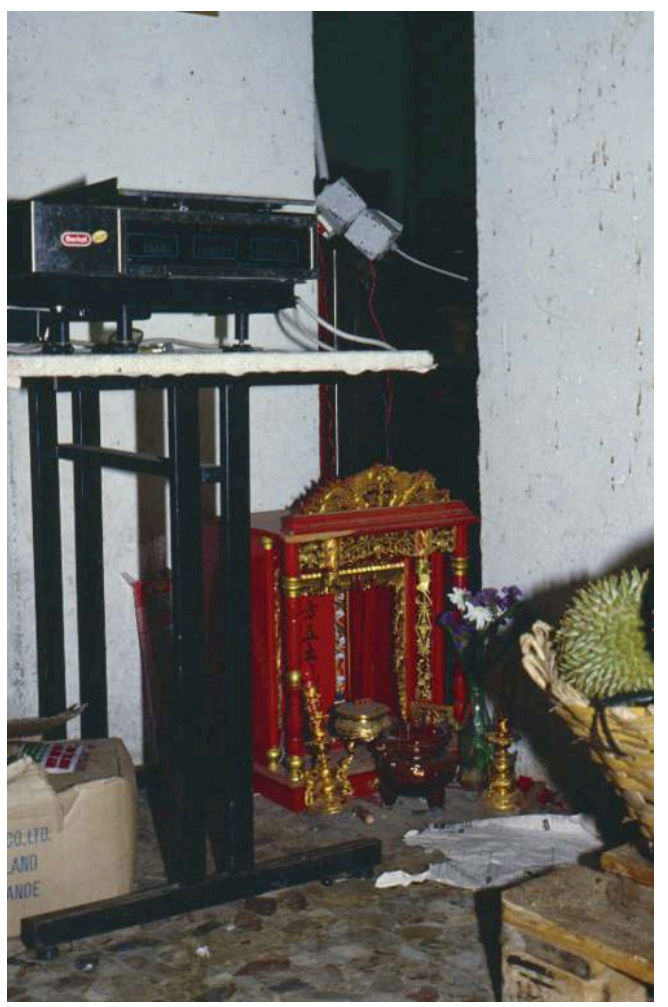

Credit: A. Raulin, Paris, 13th arrondissement, 1990. 
Photo 13: Shrine to the god of the land, Chinese restaurant

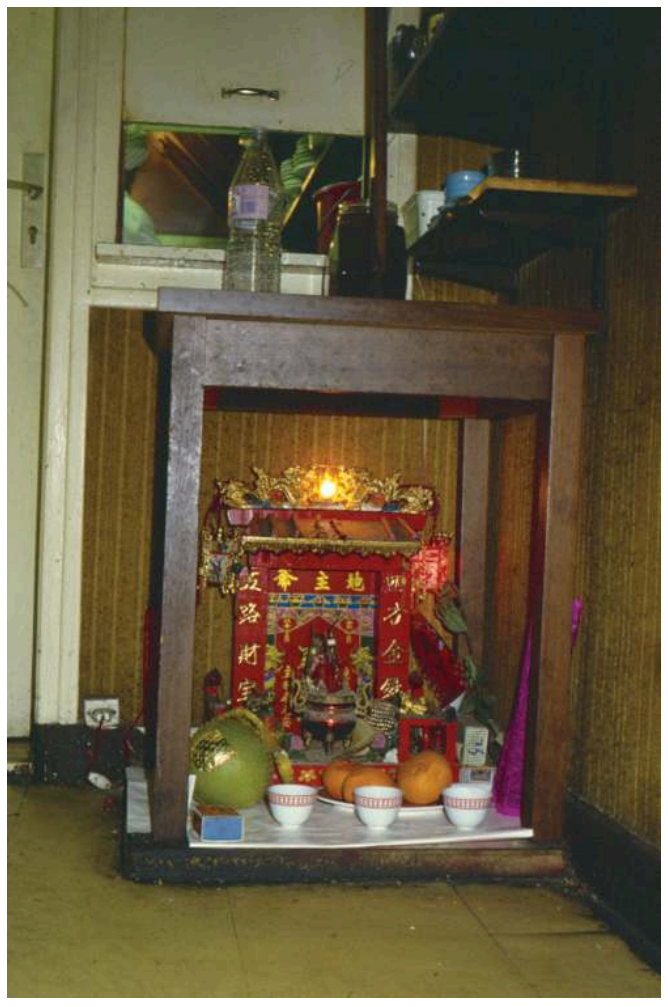

Credit: A. Raulin, Paris, 13th arrondissement, 1990.

Photo 14: Shrine to the god of the land, clothing store

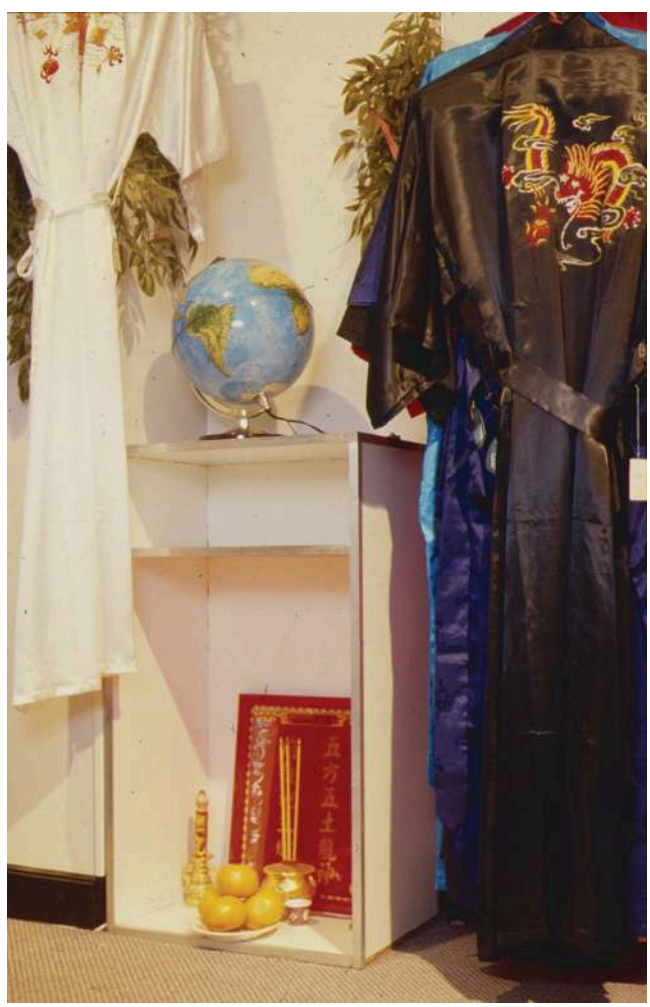

Credit: A. Raulin, Paris, 13th arrondissement, 1990. 
Photo 15: Shrine to the god of the land, illuminated

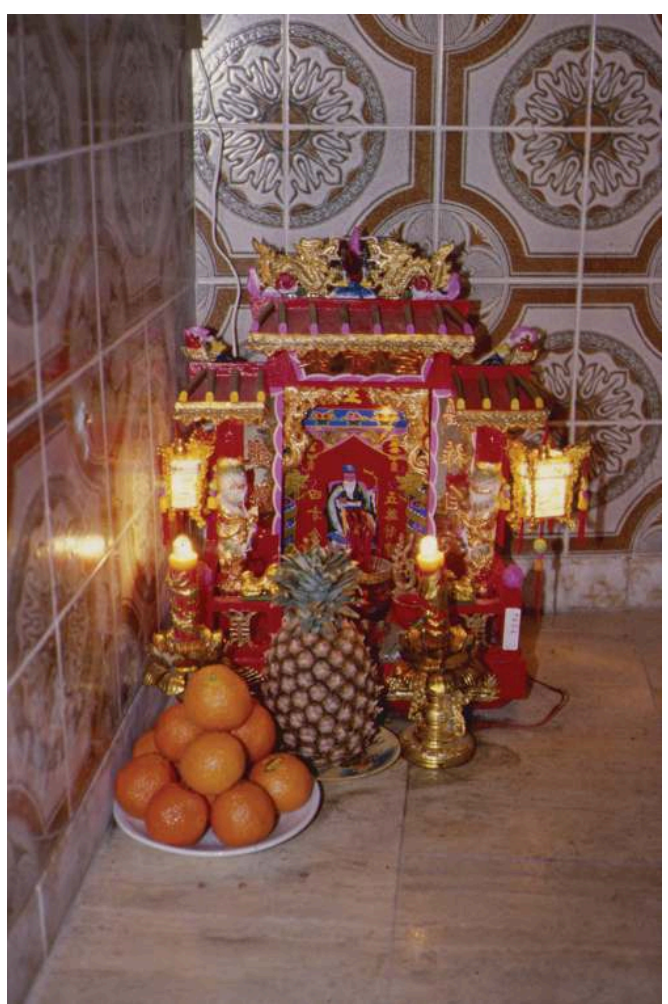

Credit: A. Raulin, Paris, 13th arrondissement, 1990.

Offerings may be richly composed and subtly lighted, and they always come with incense sticks that are lit daily while praying for prosperity (photos 15 and 16). Especially during festive periods, their presentation manifests a concern for aesthetics calling on a range of colors, the most basic of which is red, symbol of prosperity. Fruits and flowers also appeal to prosperity, health, and longevity though homonymy. 
Photo 16: Shrine to the god of the land with statuette of the deity

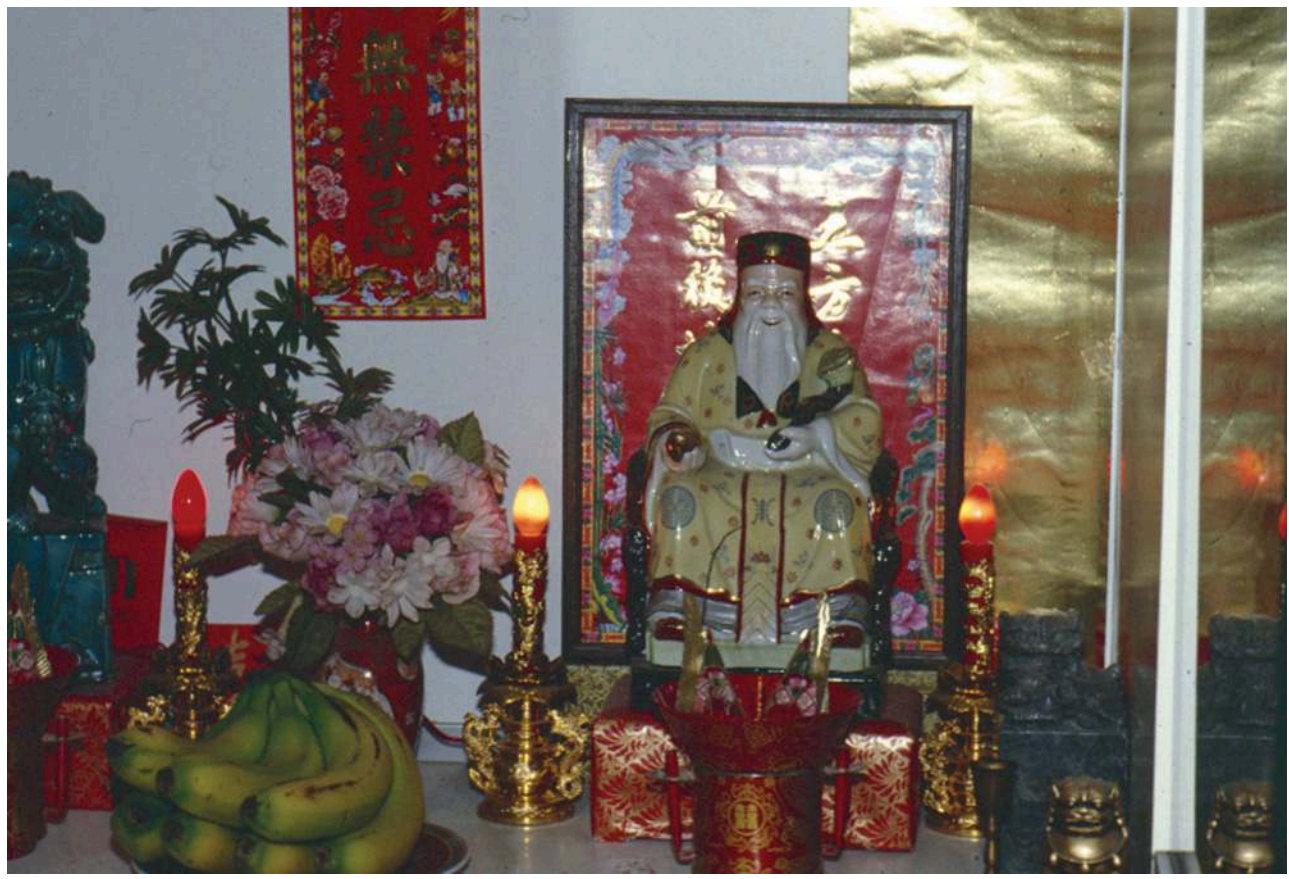

Credit: A. Raulin, Paris, 13th arrondissement, 1990.

Every shrine occupies a specific position depending on which deity it honors. To the contrary of shrines to the god of the land, those to Guan Yu are placed high on the wall (photo 17). Guan Yu was a historical figure, a third-century Chinese imperial general that gradually attained the status of literary hero thanks to the Romance of the Three Kingdoms ${ }^{12}$ and then that of deity of wealth. His red face (a reminder of his exploits) and his martial bearing speak to his power and ability to thwart dishonest dealings.

Photo 17: Guan Yu, deity of businessmen

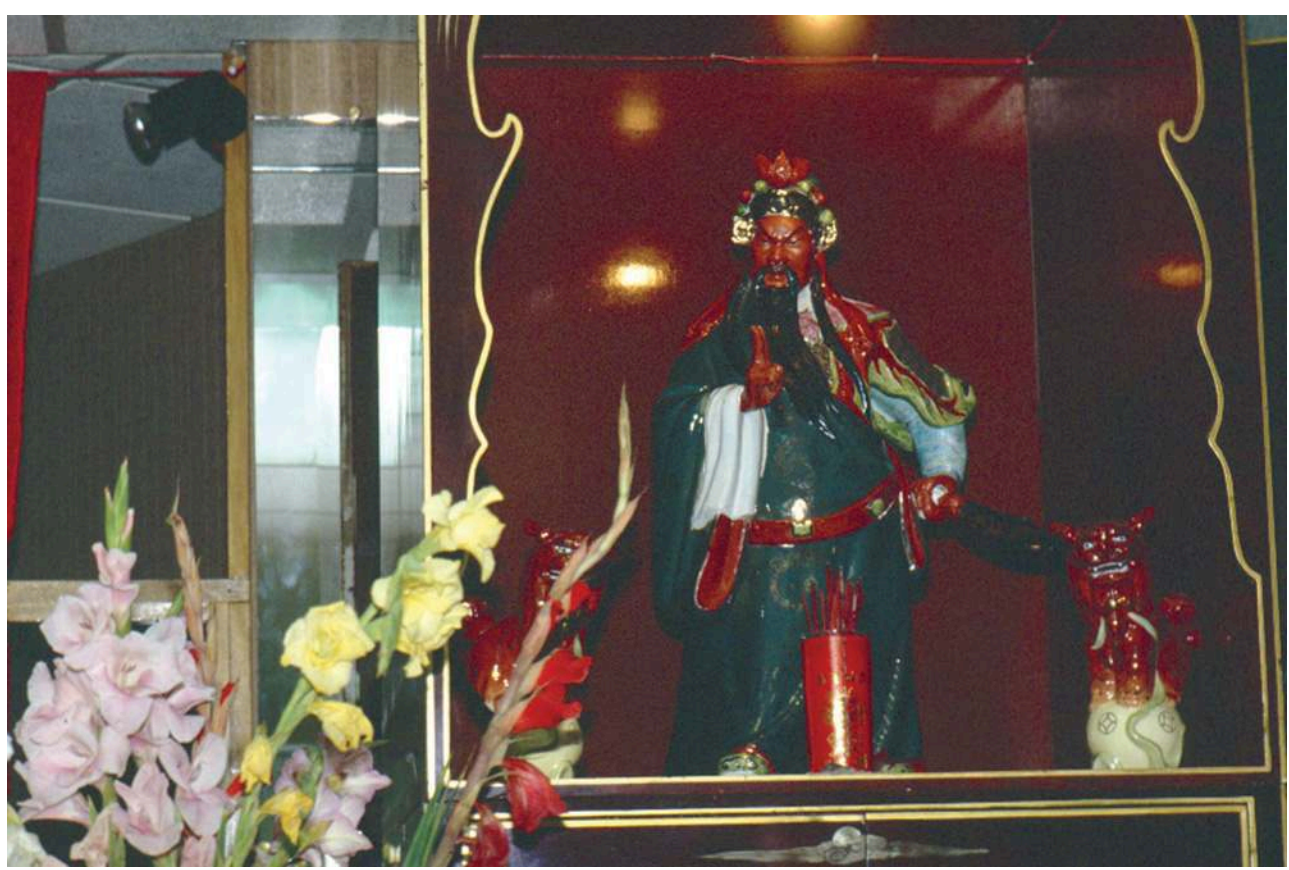

Credit: A. Raulin, Paris, 13th arrondissement, 1990. 
Photo 18: Guan Yin, bodhisattva of compassion, supermarket

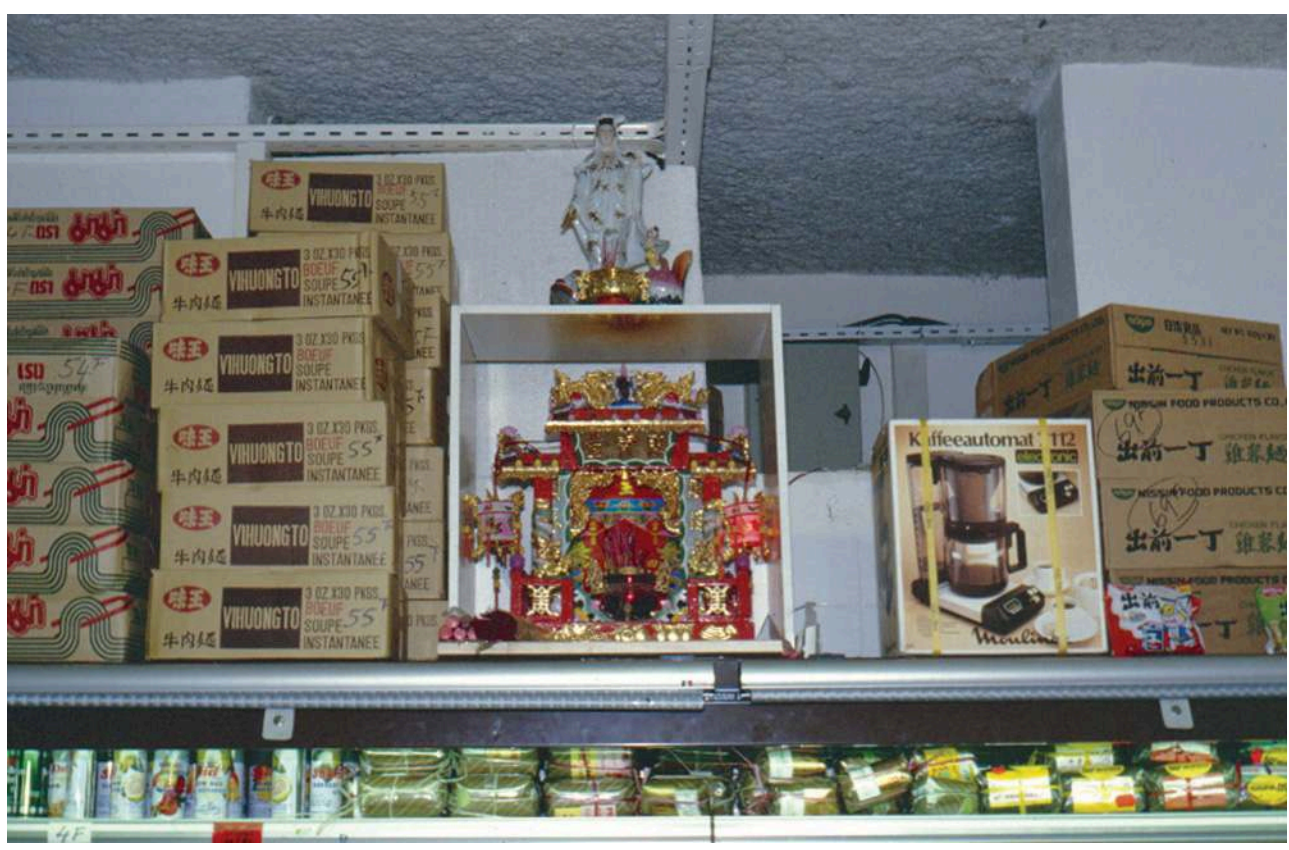

Credit: A. Raulin, Paris, 13th arrondissement, 1990.

The only Buddhist deity represented with a female aspect, Guan Yin is the goddess of compassion and mercy, specifically venerated by women, and she is also given a lofty position (photo 18). Her worship is less directly related to prosperity because she is reputed to give enlightenment and healing in all its forms. In this image she is at the top of a stack of shrines over a refrigerator, alongside boxed merchandise. A minimal form of such shrines is also placed in empty business locations to protect the space and ensure future success (photo 19). Other, more baroque propitiatory deities such as the Maitreya Buddha (the big bellied figure commonly called "the laughing Buddha") are de rigeur on restaurant counters. 


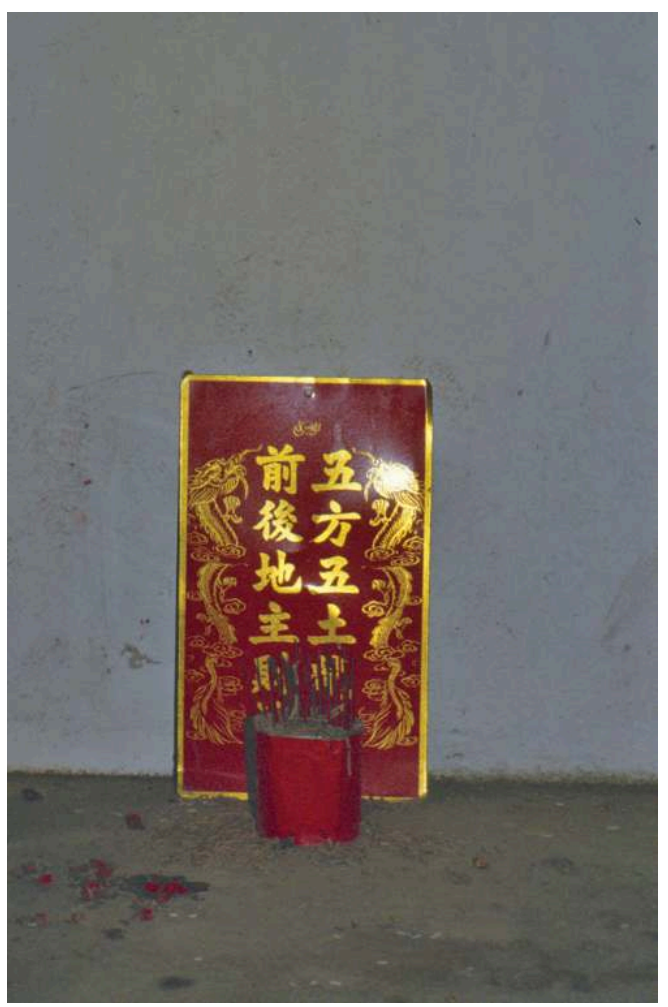

Credit: A. Raulin, Paris, 13th arrondissement, 1990.

At this stage, the photographic project is purely ethnographic and the attention to description serves to restore the aura of belief to the shop's aesthetics, transforming these rather kitschy decors into places for living and communicating with the divine. The shrines are maintained daily. The snapshots are not trying to sublimate their subjects, but rather to show their everyday lives, where restaurant work may put it in frequent contact with impurity and dirt. The offerings are both standardized and personalized, and are more consequential on certain dates important to worship in several religions, particularly Buddhism, Taoism, and Confucianism. Their pragmatic purpose is obvious and embeds the economic into an "ecosystem" that includes the supernatural. The commercial décor and scenery contribute to the successful operation of the shop, fostering circulation and a relationship of exchange between material achievements and invisible worlds.

It is significant that these practices happen in small family-scale businesses. They call on prosperity to fill these businesses, which may resemble family settings in terms of the place (the shop willingly hosts family activities, and employees participate in family circles) as well as in the spirit of that particular kind of capitalism. Wealth is desired without moderation in order to nurture happiness, which comes with significant ancestry, kinship, and descent, as is illustrated by the numerous family ritual occasions, New Year, weddings, birthdays, and funerals, which are all occasions for symbolic transactions with the ancestors (Wang 2015).

This ethnography of shops leads us to consider relations between the religious and the economic, whose premises were presented by Max Weber. Did the protestant ethic, with its a remarkable affinity with modern capitalism, suppress other spiritual representations in service to the accumulation of wealth? Obviously other ideological 
motivations and ethics (environmental, for one) can serve this system, as the practices described here demonstrate. Should they be considered as marginal or minor? They nonetheless allow us to consider the plurality of sacred or profane ethics that co-exist with the spirit of capitalism, old or new. And indeed, other situations would support this hypothesis: the collapse of socialist planned economies left room for the return of Christian and Muslim religious practices in businesses in the former Soviet Union (Tocheva, 2015), and contemporary protestant evangelism promotes a new "theology of prosperity" that takes advantage of the association between the ideology and economy of wellbeing (Luca, 2012).

\section{Photography, Witness to a Life between Presence and Absence. Contribution by Ines Ebilitigué}

The use of photography in anthropological research raises many questions. Is it simply illustrative? Does it contribute to demonstration? What specificity does it have in anthropological discourse? (Pezeril, 2008). When this use is linked to migration, the function of the still image seems to be self-evident, for the photograph immediately appears to act as a means of preserving that which characterises the migratory condition, presence in absence. As an object of migration, the photo records and displays a trace of the migrant, in the same way as the letter or recorded message, as referred to by Sayad (1985). Apart from this function of the image internally to migration, what meaning can be attributed to photography within research on the topic of migration? By mobilising photography, one does not elude the need to understand the "irreplaceable [contribution] it makes to knowledge about man, and to knowledge of man" (Garrigues, 1991: 11). Aware of its illustrative quality, some authors such as Conord (2002) incite us to go beyond this aspect alone. Piette (2007) succeeds in doing this by recognising that in anthropological discourse the fixed image has a function of objectifying reality and a power to designate. It is these same functions that this article considers, showing how photography gives visibility to a dimension that is equally dear to studies focusing on immigration and to migrants themselves, absence and presence.

In the context of immigration, absence and presence, as subjective categories, do not seem easy subjects to photograph, as they are difficult to objectify. However, can we not argue that they are displayed by the "commercial scenographies" (Raulin, 2000) that develop in urban space? And indeed, what or whose absence and presence are we talking about? The absence and presence of the place of origin, which contains objects, food practices, institutions, traditional values, figures, etc. This absence is sometimes translated into an assemblage of discourse, a message conveyed by the objects photographed, such as signs and shop windows, but also in a fortuitous arrangement between space, time and passers-by, whose movement and directions reinforce what the photographic media tell us over and over again. This is illustrated in photo 20 . 
Photo 20: The urban theatre: between departure, absence, stopover and arrival

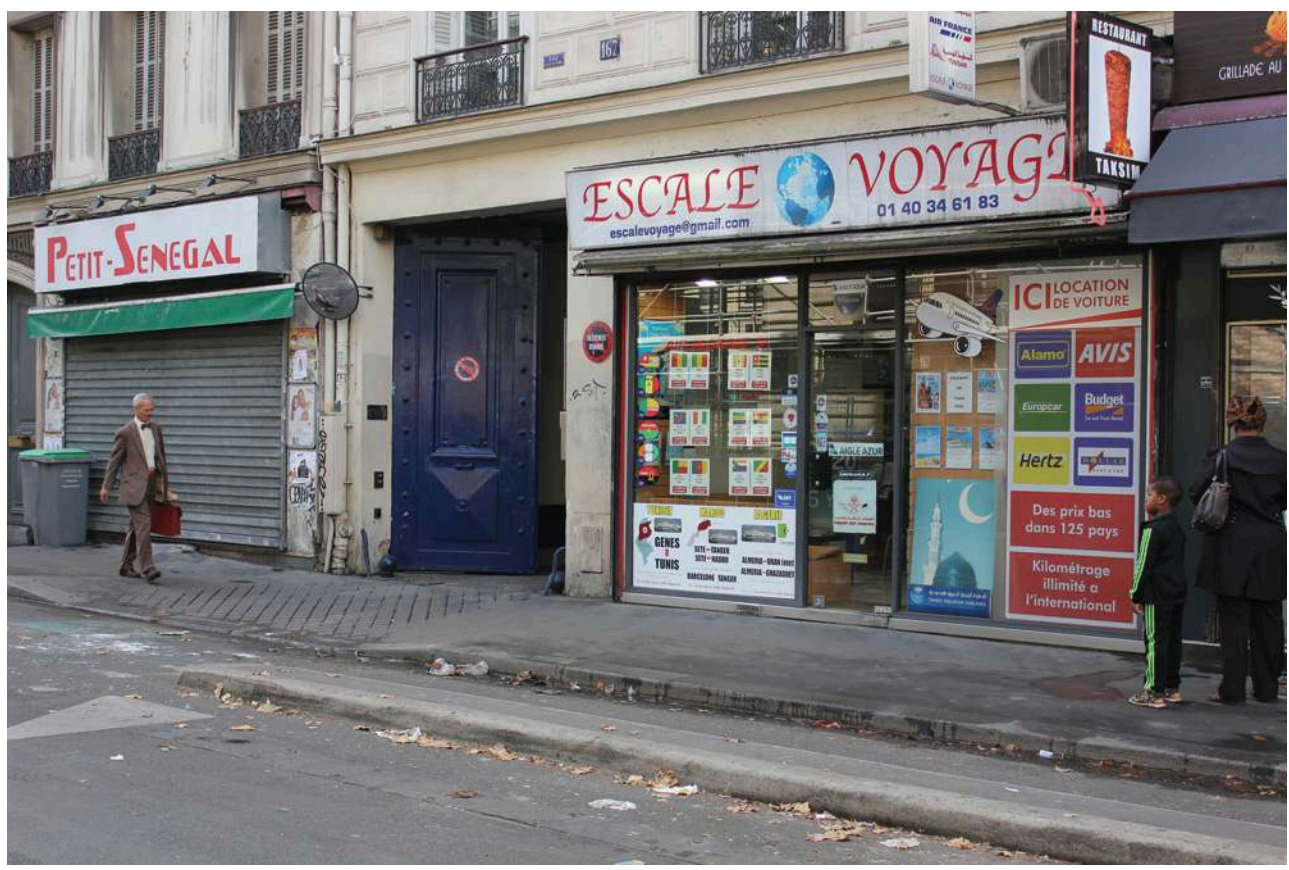

Credit: I. Ebilitigué, boulevard de la Chapelle, Paris, 2015.

38 This shot provides a glimpse of a movement going from a given territory, through a stopover, to an arrival point. The signs and windows of two shops form a scenic backdrop in which a passer-by, carrying a briefcase, seems to be leaving the Petit Senegal, to make a stopover before being welcomed by a little boy who is standing with his body almost static and turned towards the man, as if to welcome him. The particularity of this image is that it presents an urban setting in which the parts played by unexpected actors' are articulated and stand out in the fabric of an urban theatre, without any consultation between the actors and without them even realising the reading they may present of the situation captured by the photograph. It "displays a power of designation that ensures its basic heuristic quality: to show, to do, to see, to attract our attention" (Piette, 2007: 23). "Something resonates" (Moles, 1990), in the sense that the photo appears as a summary of the analysis conducted by the anthropologist, like a coincidence between reality and the researcher's questioning.

Photo 21 points more towards absence by evoking nostalgia for the home country through the evocation of key reference points for migrants, namely the figure of the mother and the territory of origin, as the sign Mama Afrika indicates. In addition, in ordinary shops as in the tobacconists where there is no apparent sign of the migrant's daily life, one can nonetheless detect the blue cans that serve as secure luggage containers for the transport of various goods to or from West Africa or from this part of the world. 
Photo 21: Nostalgia for the home country, from the grocer to the tobacconist

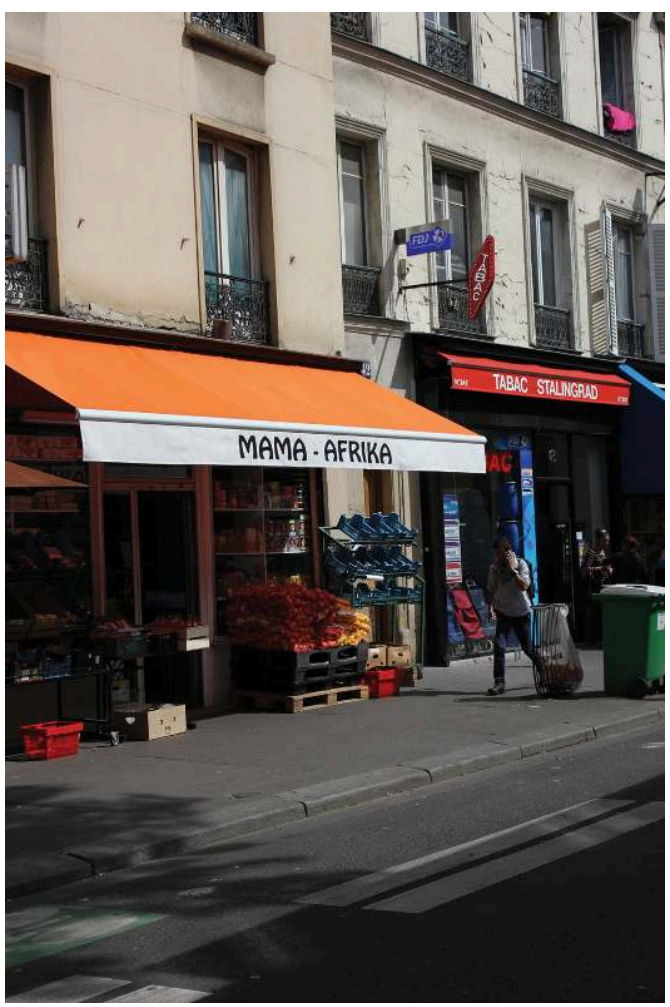

Credit: I. Ebilitigué, boulevard de la Chapelle, Paris, 2015.

40 Under the sign of La Bamakoise (Photos 22 and 23), we find a stand displaying food and domestic products, supplies the mother is in charge of gathering. At the back of the shop there are objects that are recognisable only by an African clientele, such as traditional brooms made of long fibres bunched together, placed above a refrigerator unit along with other decorative objects. 
Photo 22: Sign of La Bamakoise grocery

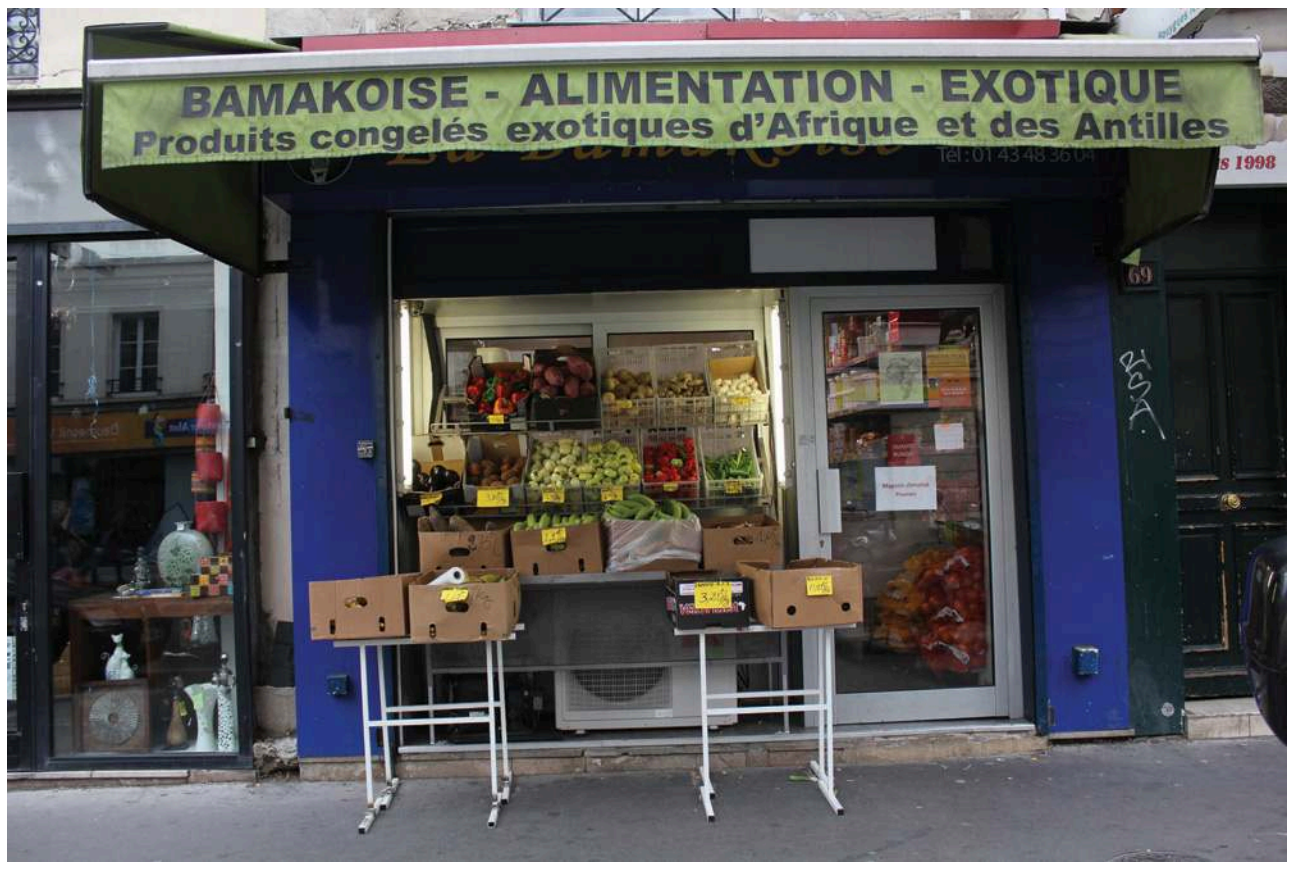

Credit: I. Ebilitigué, rue d'Avron, Paris, 2015

Photo 23: Interior of the La Bamakoise grocery

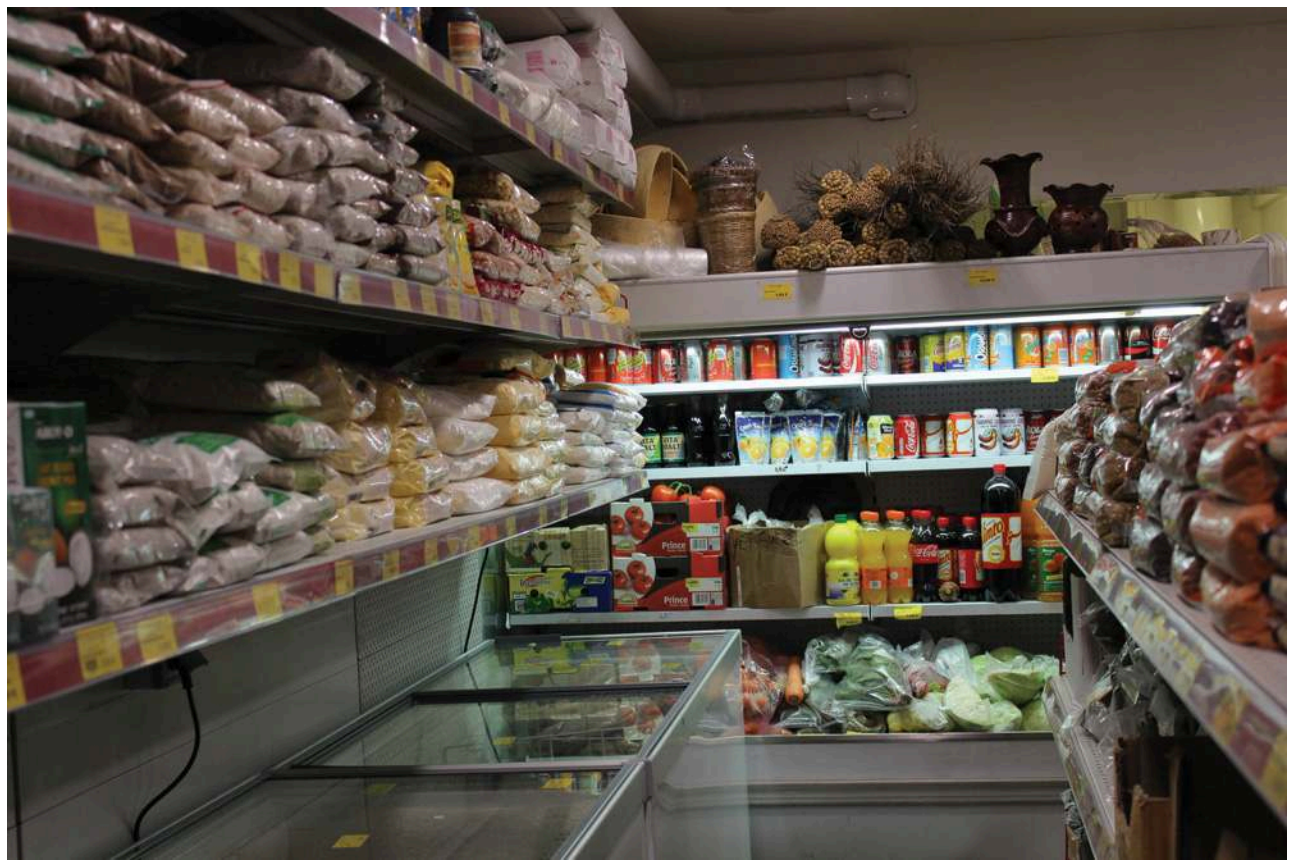

Credit: I. Ebilitigué, rue d'Avron, Paris, 2015

41 This back and forth between places of departure and places of arrival, through the intermediary of tangible goods, will, in these same shops, be enhanced by another dimension, one of a virtual nature this time (Photo 24), but nonetheless giving a real presence to the absence. It is no longer about edible and material consumer goods that recall the home country, place of origin and family living there, but about media 
services that make it possible to establish immediate connections with those absent and therefore to be present for them in another way, one that is virtual but direct.

Photo 24: Advertisement with multiple faces

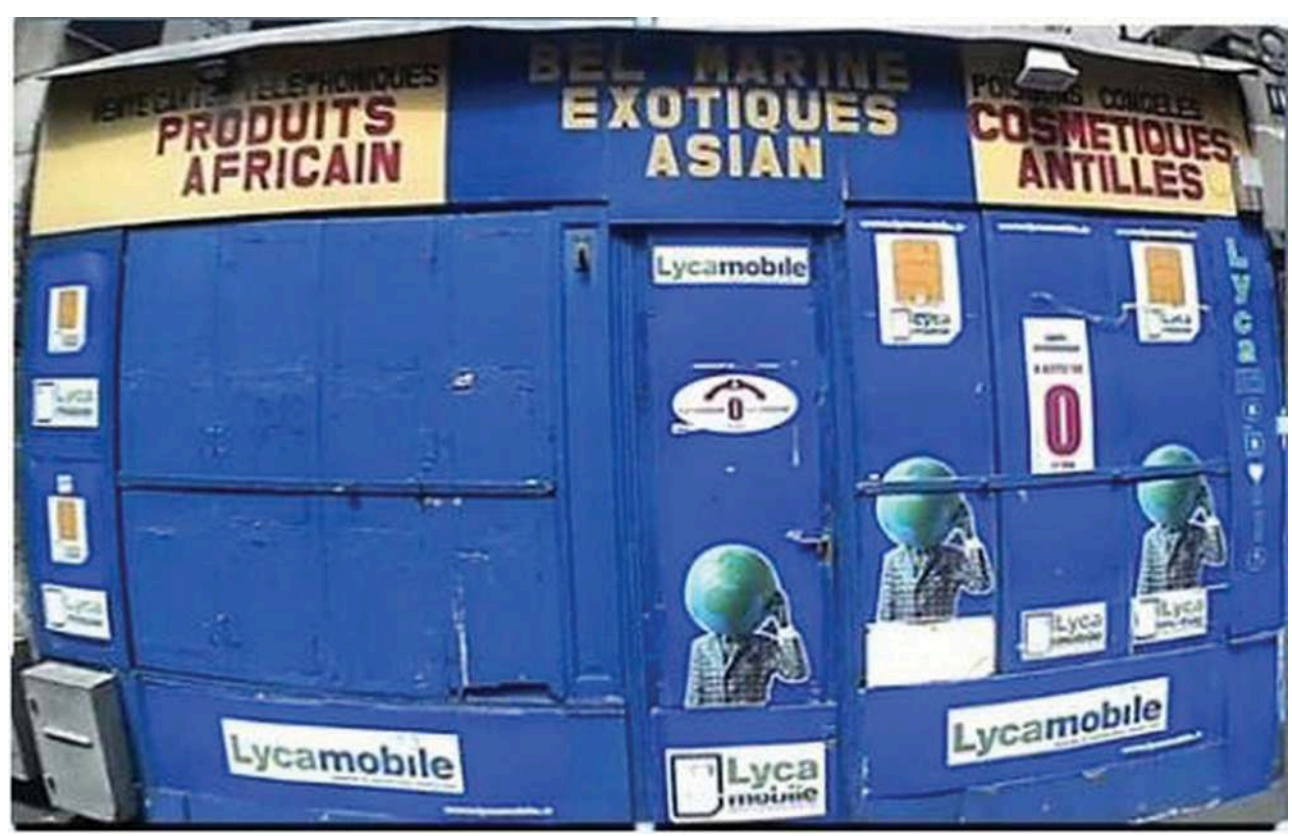

Credit: I. Ebilitigué, avenue Jean-Jaurès, Paris, 2015

These advertisements, whether figurative or abstract, produce a discourse on absence, whose message seems imperative. They incite all migrants concerned by the absence of "loved ones who are far away" to recognise themselves in this commercial message and to identify with this mascot whose head is represented by a globe.

In the course of this study, the act of taking photographs came up against numerous refusals from merchants who were reluctant to let an unknown woman enter their space as they did not see it being in their interest. After various attempts using a hidden camera (built into a pair of sunglasses) whose image capture was of poor quality, the solution adopted was to take pictures from the street, with or without permission, but also in the shops when allowed. While the photographic quality was not necessarily optimal, the processing of the documentation gathered in this way was very satisfactory. It was clear that these businesses are not only providers of goods and services, but also places offering opportunities for cultural links, which each establishment was skilled at advertising.

The notion of link here encompasses all parts of daily life and reflects the symbolic or real relationship between urban migrants and their cultures and countries of origin. This activation of the cultural connection takes place from an urban setting, in specific places of frequentation, through the intermediary of merchants who recreate environments and display goods and a style that are meaningful in relation to the practices of customers, satisfying their imagined mobility between the country of residence and the country of origin. It is in these imitation vernacular shops that traditional goods and commercial electronic connection services such as telephone cards and chips are found: these items enable immediate interaction with family members still living in the home country and thus making them present to those who 
are absent. The dimensions of reality, imagination and the virtual are articulated as a result, as well as the registers of tradition and modernity, or of here and elsewhere. Contrary to what is usually thought, they are not opposed, but are combined in the lived experiences of the concerned individuals.

In this way, a form of ubiquity, of double or even multiple presences is practised by city dwellers in relation to their countries of origin and their families still living there. It is a specific trait of the migrant experience, that this mobility is not solely physical, but also commercial, communicational and part of the imaginary. And this trait can be found displayed in the city, in the storefronts that propose these cultural links: it is this "ode to mobility" that photography manages to capture.

\section{The Shisha: An Object of Contemporary Migration Turned Object of Urban Research. Contribution by Alexa Färber}

Since 2003 the shisha has provided a new perspective for me in the field of urban research - sometimes as part of ongoing research projects, sometimes out of personal curiosity. This duality of the shisha in my professional journey as an urban anthropologist has evolved: from a simple object that I encountered during several stays in Arab countries, to its status as a symbolic research object that captures various forms of ethnic glamorising in the consumer landscape of Berlin. I took as my subject, and point of departure for a comparative study of Moscow and Berlin, the status of the ethnic in world cities: could the concept of world city, which is valid for cities in the West, be applied to these two capitals, which were undergoing post-Soviet or postSocialist transformation? Could it give a full account of the experiences of their inhabitants? Since world cities have the capacity to make the ethnic participate in their cultural and economic life - albeit under capitalist conditions - this perspective was, together with Cordula Gdaniec, my point of comparison for highlighting specific characteristics of Berlin and Moscow (Färber and Gdaniec, 2004).

What was interesting about smoking a shisha in 2003? Observers who are attuned to consumer spaces, so-called "ethnic" economies and youth cultures confirm that the shisha created for itself a new - and eminent - niche on the streets of Western cities in 2002-2003: in local shops and tobacconists, restaurants and cafés-bars, as well as private spaces. These varied backdrops make the shisha, already perceptible from the street by its scent, even more visible as an invitation to a multi-sensory experience. 
Photo 30: The bar in Berlin of a shisha café

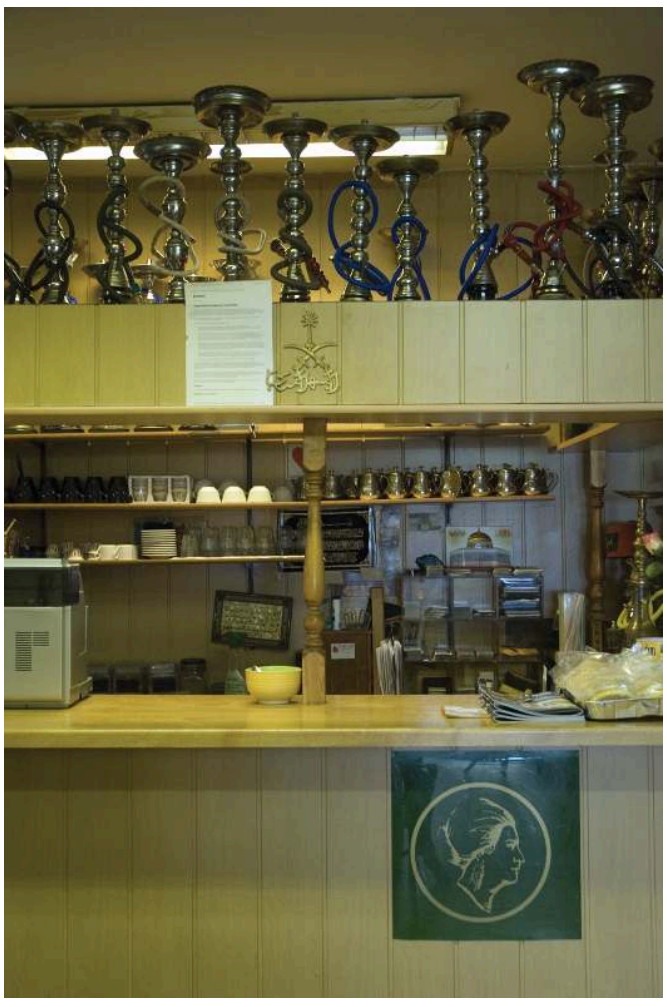

Credit: S. Helmerding, Berlin, Neukölln, 2009.

Photo 31: Sign for a restaurant with shisha section

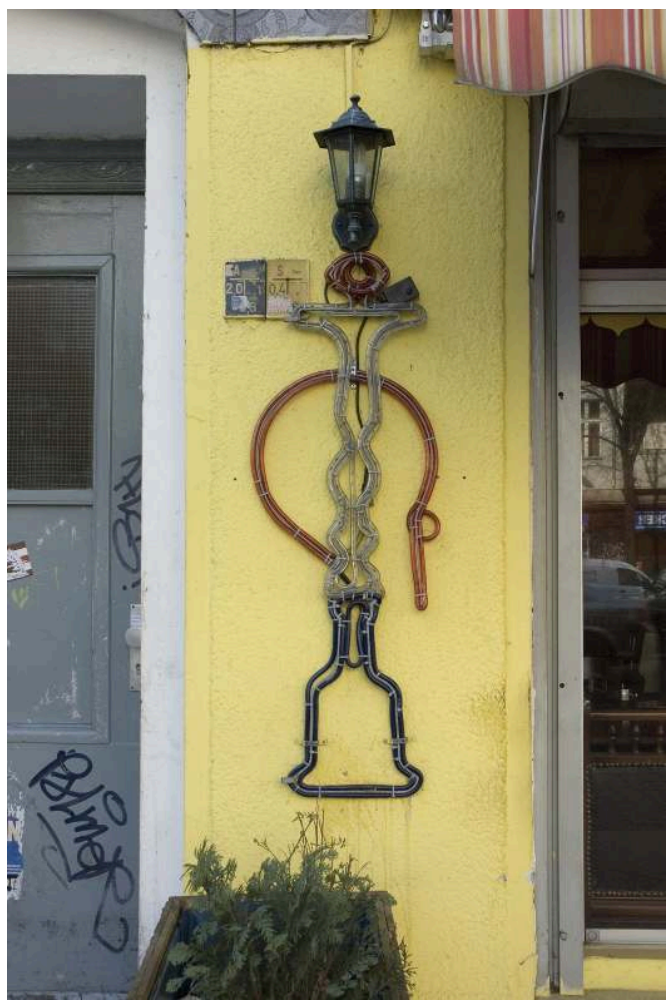

Credit: S. Helmerding, Berlin, 2009. 
I identified three types of establishments where shishas - also known as narguile (France), kaljan (Russia) or hookah (US) - could be smoked: Arab cafés, casual cosmopolitan bars and Oriental bars. The Arab café's claim to originality is being a traditional café mainly frequented by men, where coffee and tea are consumed but no alcohol, where patrons play backgammon or watch Arab TV channels, especially Egyptian films from the Farid al-Atrash era or Umm Kulthum videos (since news would risk dividing the clientele). This Arab café is "ethnic" only in pan-Arab terms and, in Berlin, its customers are largely first-generation Arab immigrants, mostly of Lebanese or Palestinian-Lebanese origin. Young men will stop in briefly to smoke a shisha, say hello to their fathers, uncles and family friends, or to avoid venues that are more frequented by their own generation. Berlin's casual cosmopolitan bars originated in a post-multicultural context that transcends the side-by-side existence of clearly differentiated, multiple (ethnic) cultures by practicing a "daily cosmopolitanism" (Römhild 2007) closely connected to its consumable form. This kind of bar affirms the hybrid nature of cultural references. It speaks both to upwardly mobile, secondgeneration immigrants (of Turkish and Kurdish rather than Arab origin) and to an adult clientele that has travelled and cultivates a taste for the Other, symbolised by its consumption of exotic products. The distinction that suits customers and owners is that of a refined taste shown through quality products, tobaccos and drinks. The third type of venue for smoking a shisha in Berlin is, for want of a better term, the Oriental bar: "bar" in the sense of an ice-cream parlour where young people congregate in the afternoon or evening to encounter other people, senses and substances, and to explore a certain ambiance. They go in mixed-gender groups of friends and consume alcohol as well as shishas of all flavours. Here, styles and objects are as diverse as the family origins of the young consumers: they reflect the statistical cartography of the inhabitants' ethnic origins in the neighbourhoods where these local bars are located.

\section{Photography's Instantaneity, the Urban and Urban Research: An Elective Affinity}

Unlike the coffee-to-go of the urbanite in a hurry, the shisha stands out in the consumer landscape of world cities by its relaxed attitude towards time: it is primarily a pastime that allows the smokers to consume flavoured smoke while contemplating the urban scenes passing before their (groggy) eyes.

50 A striking contrast between this pastime and the characteristics of photography as a medium is that while the shisha celebrates the long duration - and we will see that this rests on matching visual imagery - photography expresses the instant. This is specific to photographic technology or, as Dubois (1990) calls it, the photographic act. The world is seen through this temporal self- reference, with the photographic act reflecting above all the instant of the snapshot. This instantaneity creates a real affinity between photography and the singular experience of the city with its multiple scenes competing with each other. A glimpse of a street and its passersby, a neighbourhood and its inhabitants, or a city and its population is nothing less than a moment already past, a situation already in the process of changing, an object that is subject to a project of transformation or urban development. This elective affinity of the urban with photography is reflected in the history of photography (Cuny et al, 2014). 
Thus, the visualisation by photography of shishas and their multiple insertions in the city can only occur under a certain amount of tension: the instantaneity of urban photography contrasts with the extensive temporality of the shisha. Perhaps it is this incompatibility which led photographer Silke Helmerdig not to take photos of shisha smokers, serenely waiting for time to pass ever so slowly, but to favour instead objects that are "ready-to-go", to be bought and dispersed in the city or used in a café (Photo 30), or else the signs that intrigue passersby and alter the urban scene (Photo 31).

\section{Multiple Derives and the Compilation of an Archive of Instantaneity}

Let us look more closely at the shisha's slow imagery and its potential for visual research. My archive of shisha images only gradually diversified. Colleagues sent me their photos of shishas or shisha-bars taken randomly on their strolls because the objects made them think of me, or my research. Fortuitous discoveries sent me on unexpected research paths: Werbebildchen or colonial postcards (Figure 1), reproductions of paintings and Orientalist travel narratives, modern tales and the lyrics of contemporary songs, newspaper articles and photos, or tourist objects. This is how I compiled my multimedia documentation, which is not always easy to use.

Figure 1: The Orientalist Imagery of the Shisha

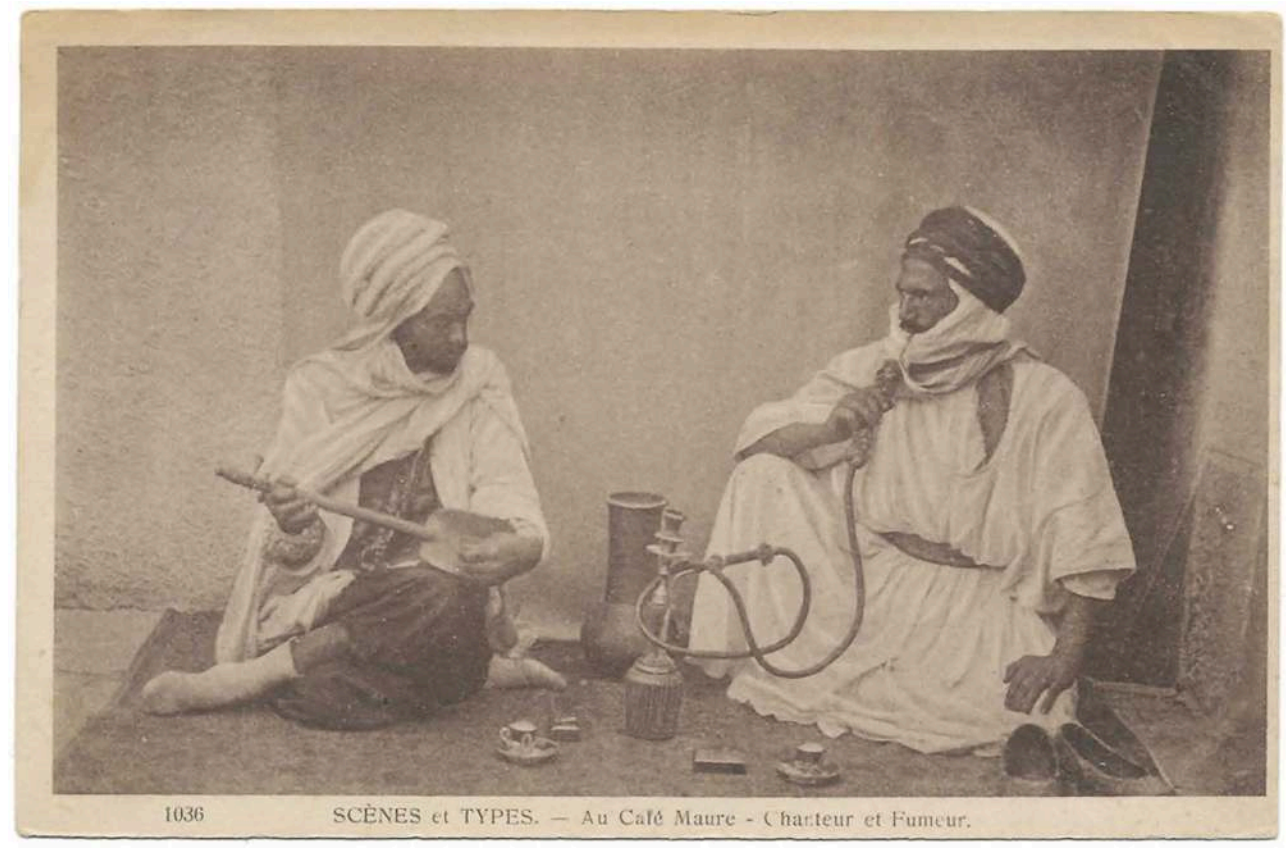

From: Postcard entitled "1036 Scenes and Types - In a Moorish Café - Singer and Smoker" (no date). 
Figure 2: The Escapist Imagery of the Shisha: The Shisha Smoking Caterpillar

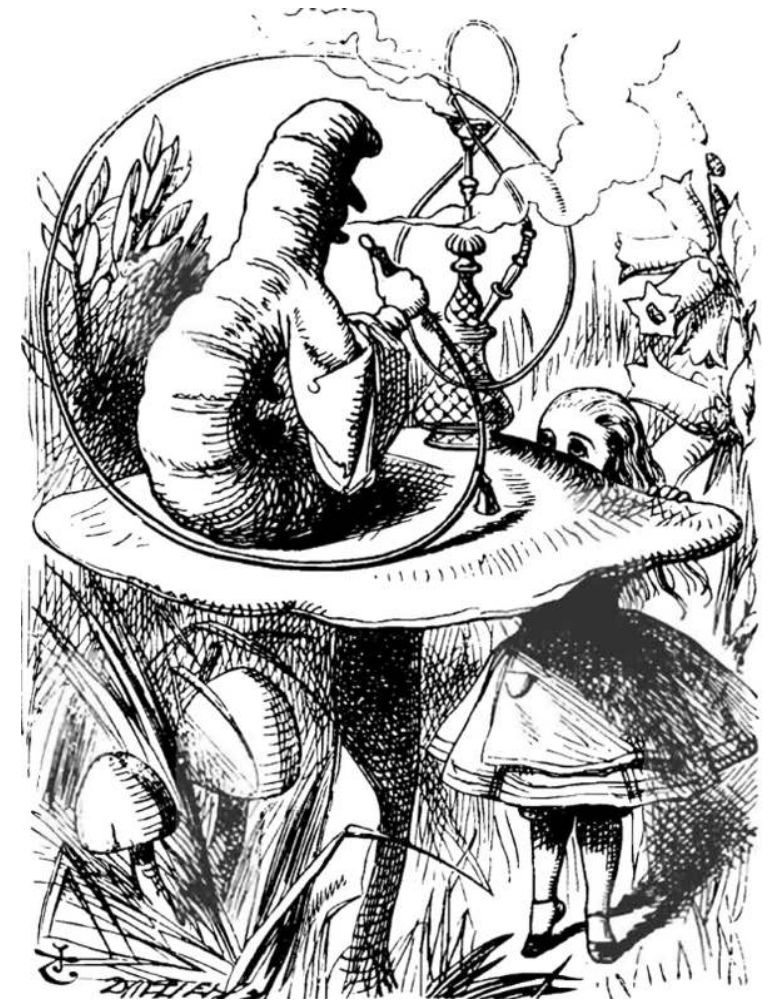

From: Illustration by John Tenniel for Lewis Carroll, Alice's Adventures in Wonderland, 1865.

53 Thus, Orientalist painting was interested in the aesthetic value of the shisha in its representation of the Other in spaces segregated by gender. But to derive a visual genealogy leading to today's shisha-bars and their patrons' self-exoticisation would require in-depth research - and research of great interest - on the work of café and bar decorators and their collection of "Orientalist" images and objects, in order to understand how visual representations circulate and how they are staged multidimensionally. The same holds true for intertextual or inter-media references: the wise shisha-smoking caterpillar, who explains to Alice in Wonderland (Figure 2) the benefits of increased perceptiveness brought on by smoking, reappears today in both film representations and music. During the journey through time, and from one medium to another, the layers of meaning change. In Jefferson Airplane's Top-Ten hit, "White Rabbit" (1967), its "shisha- smoking caterpillar" is seen as being an initiation into psychedelics - which has no equivalent in Orientalism and is far removed from the imagery that has currency in today's shisha lounges. Jefferson Airplane does not feature on the playlists of the establishments I visited.

\section{Multiplying Visual Expressions}

Research into visual representations of the Other in the context of migration in worldcities can rely on archives of varying densities, temporalities and uses. Alongside documents made from various materials, photos also have diverse qualities depending on the requirements and stages of the research project.

Photographs as visual note-taking constitute a large part of this (Series of Photos 32). They feature as a logbook, their instantaneity being reinforced by digital photo-taking 
technology. While they serve as an archived memory, and can be integrated into presentations of the PowerPoint kind, they rarely lend themselves to reproduction in print due to their low technological and aesthetic quality (as their miniaturised reproduction here shows), which at the same time reflects the instantaneity of the photographic act.

Photo Series 32: Photographic Note-Taking

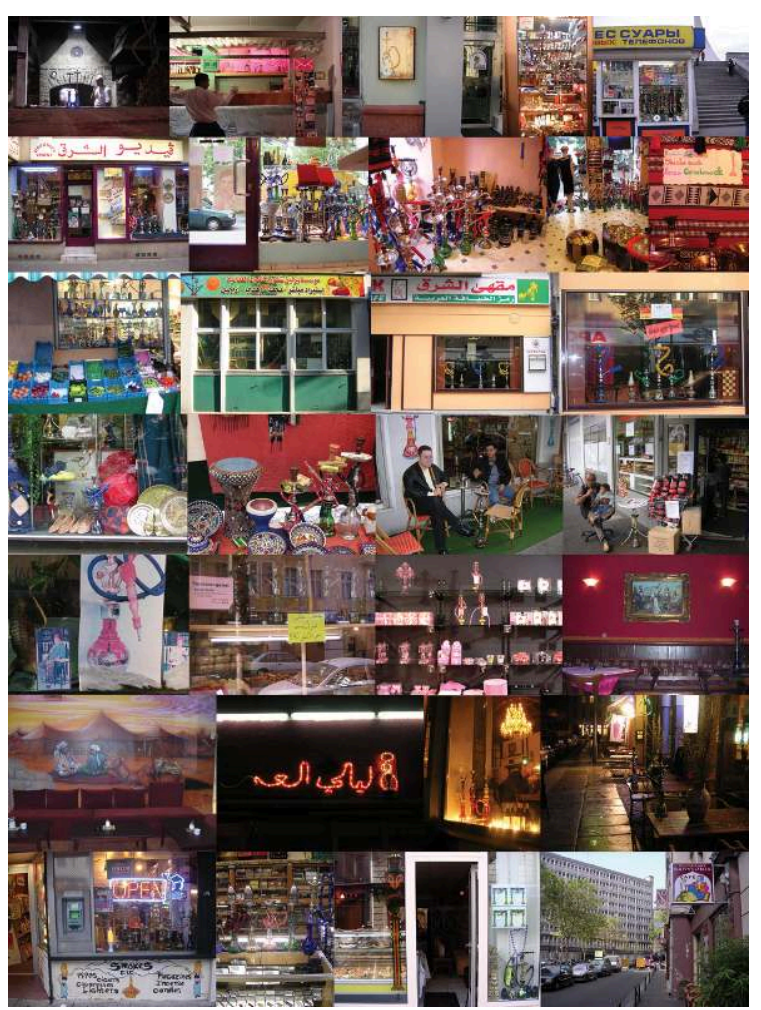

Credits: A. Färber, Moscow 2004-2005 (first line), Berlin 2003-2006 (lines 2 to 6), San Francisco, 2005 (line 7, the two photos on the left) and Paris, 2007 (line 7, the two photos on the right).

If we return to professional photographs suitable for publication, the cooperation between professionals from the visual arts and urban research offers potential results that are suitable for the exigencies of each discipline. However, this cooperation needs a reciprocal understanding of professional practices and their possible convergences.

It is precisely to understand the modalities of such interdisciplinary collaboration in urban and visual research that the network "Penser l'urbain par l'image" has studied the (rare) joint work published by professional researchers and photographers. It has also started its own experiments, which always take into account the multiple statuses of visual data. The quality of the photography used by urban research can be considered only just "passable", only good enough to bear witness to an observation, not stand as an artistic product. Besides, the complexity of an artistic photo can exceed what was demanded of it within the well-defined framework of a research project. The challenge therefore is to find in the collaboration between professionals in research and the visual arts modes of working that correspond to the needs of the research project whilst also remaining free enough for experimentation. This approach has to merge shared reflection on the multiple statuses of images in ongoing research with 
archives and possible forms of publication. It must learn to circulate between the different forms in which urban research exists.

\section{The space of a photograph: Looking for signs of a presence. Contribution by William Berthomière} light on the place and perceptions of this new migratory moment in the daily life of people taking the main route through the neighborhood of Neve Sha'anan, known for being the neighborhood of the Tel Aviv bus station and represented in Israeli society as a major immigration site..$^{13}$ It should be stated from the outset that I chose to use photography here as a means to broaden the field of observation, and not as a complementary resource to further focus the gaze exclusively on the immigrant population. By expanding the field of analysis in this way, this approach is mainly intended to contribute to thinking about the semiotics of the space, photography serving as a tool to reveal systems of significant signs and processes that are as many clues allowing us to deepen analysis of the daily lives of residents and passersby, those who practice these urban spaces as they change according to socioeconomic dynamics with origins as local as they are international.

\section{In quest of signs}

61 Thought of as diffuse and distinct, the clues that may be perceptible must inevitably have a materiality that makes sense. The literature in social geography that has developed around the work of Ripoll and Veschambre (2004; Ripoll, 2006; Veschambre, 2008), especially that concerning the notion of marking, is thought provoking in this regard. For one thing, the suggestion that elements of observation be attributed with a marking register is a productive one, because it spurs consideration of two of its main expressions, the trace and the mark. Beyond semantic proximity, it is all the more fruitful because it facilitates making distinctions in the register of temporality (see Table 1). 
Trace and mark both have "definitions that refer to the materialization of a presence in space, or in other words, an existence or an action," but the trace "refers rather to what remains of the past" while a mark "is part of the present" (Veschambre, 2008).

Table 1: Differences in register between trace and mark

\begin{tabular}{lcc}
\hline & Trace & Mark \\
\hline Temporality & Incarnates the past & Refers to the present \\
Intentionality & Non-intentional & Intentional \\
Signification & Anonymous. Refers more to an & Refers more to an actor \\
Synonyms & activity or event. & Signature \\
Possible actions & Imprint, vestige, clue & Maintenance/damage, \\
& Identification, reinvestment, & promotion/erasure
\end{tabular}

Source: Veschambre (2008: 11)

63 A difference emerges between our analyses, however. While they hold that one outcome of using the register of marking tends toward the idea that, "if one must give a more specific content to the marking, [...] [one might] use the definition of Brunet and others and think of it as the use of one or several indexical signs in a space 'destined to signal its appropriation"' (Ripoll, 2006), in my work this extension of the register of marking is a limitation not to be exceeded. The space of photography is not intended to build a frame with boundaries at its edges, since the intention must be focused on the everyday perceptions of passersby experiencing Neve Sha'anan, which de facto situates analysis in an approach attentive "to the life of sensations" ${ }^{14}$, but never with the aim of delimitation. Although Ripoll introduces the idea of exploring claims, who may do marking, and situations where marking is absent (which is a fruitful alternative to the notion of appropriation, suggesting that it "has the advantage [...] of stressing that the 'masters of places' (owners, possessors) and the 'excluded' are at the same level" [Ripoll, 2006]), both notions propel us toward categories making reference to the "inclusion/exclusion" dialectic that narrows our scientific horizons, making this neighborhood a "movement-place" 15 whose dynamic cannot be fixed in these terms.

64 To root myself in this reading of the marking of geographical space in Neve Sha'anan and use a semantic placing us in a register free from any form of appropriation, I found floating observation as it was developed by Pétonnet (1982) to be one of the best techniques for revealing multiple, distinct, or even plural presences. In short, I mainly called upon photography to catch the marks and traces that are as many signs to be perceived (or remain unseen, of course) by passersby, and even more so to try to emphasize the multiplicity of their forms and the diversity of interactions that they might prompt.

65 As photographs 37 and 38 show, the perception of changes undergone by the buildings of Neve Sha'anan enrich the register of markings. Even in the absence of direct interaction with migrants, the passerby can give content to the word globalization by the experience of the eye, which can read the present of a presence on a facade (as in photograph 37), seeing the metal shutters of wholesale businesses replaced by front doors and little windows for residential use, allowing any curious regard to see the development of housing for new residents in the neighborhood. And if the experience of the eye must convince itself that this perception exists in order to establish it, the 
presence of old objects, like those near the open trash can in photograph 38, are signs contributing to the process of validating the perceived situation in the present.

Photograph 37: The emergence of marks

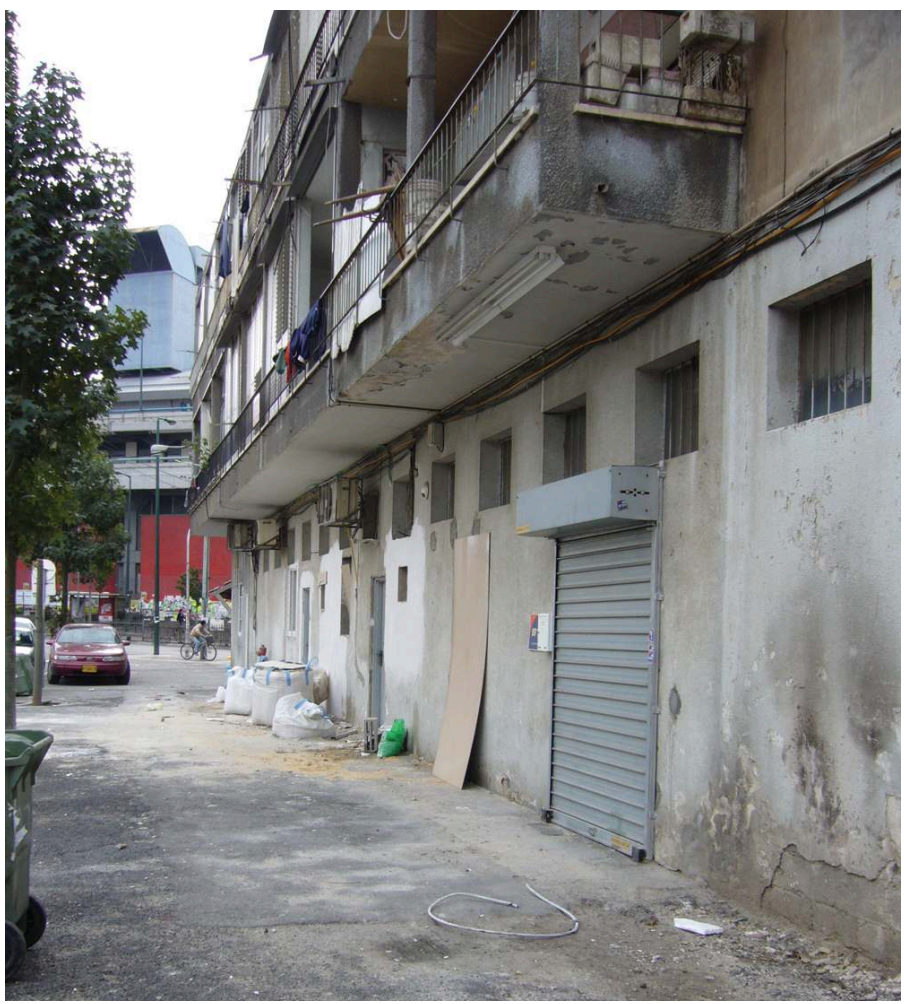

Photographer: W. Berthomière, Tel Aviv, 2007. 


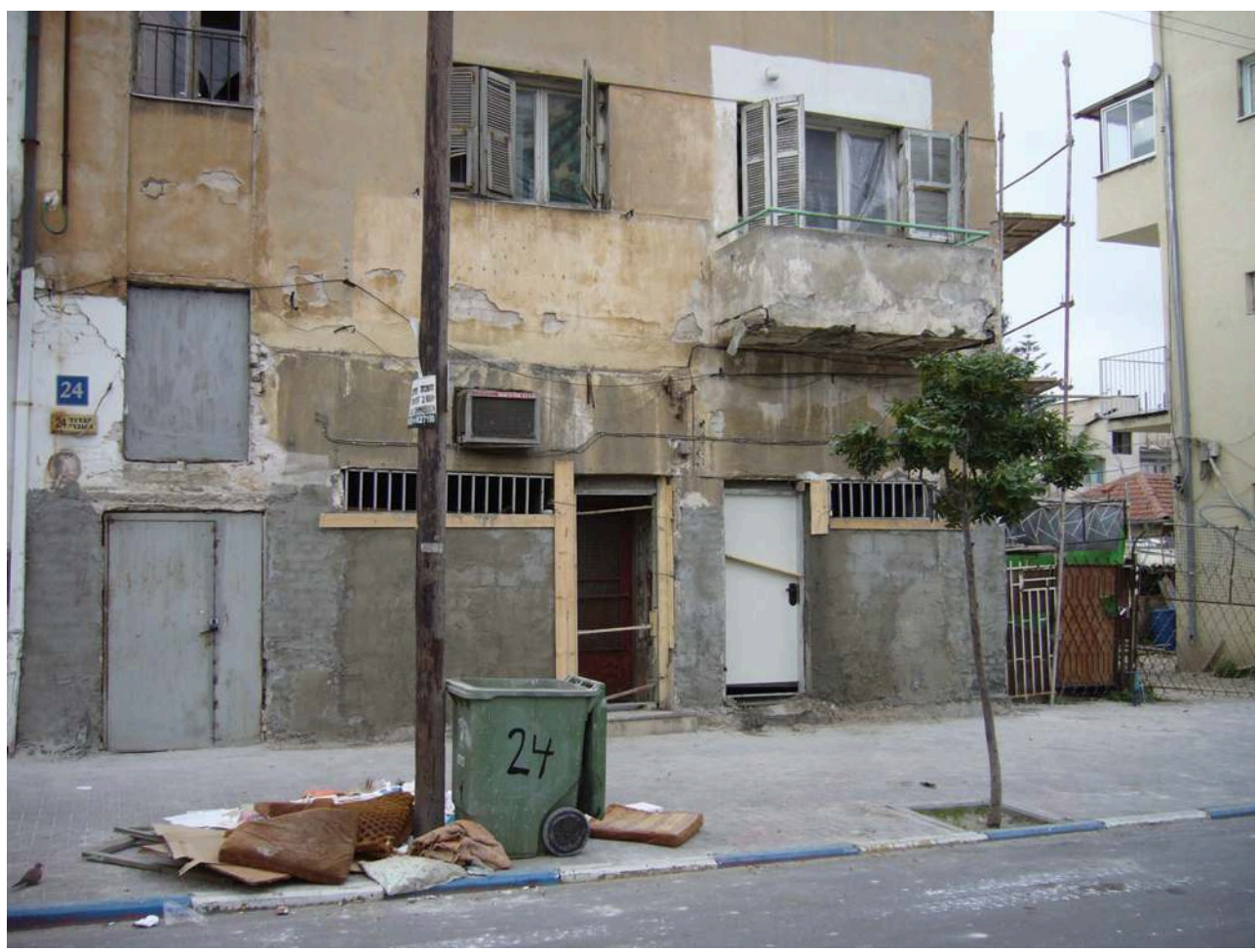

Photographer: W. Berthomière, Tel Aviv, 2007.

To this first register of marks can be added a group of signs that are unrelated to an architectural modification of the urban landscape. Over the course of hundreds of hours of wandering walking - "propitious for the strolling observations" of the flaneur (Thibaud and Tixier, 1998) - I was able to catch signs whose placement or function offered the experience of the eye a "truth-fieldsite" for the social reality of these new presences.

These marks take their place in the everyday space of passersby who may discover and decode the presence of objects along their path, like the sign tacked on a building (photograph 39) or the colorful advertising posters, one illustrated with people, that draw the gaze of passersby, thus immediately putting them into a process of identification or Othering (see photographs 40 and 41). 
Photographs 39: More marks

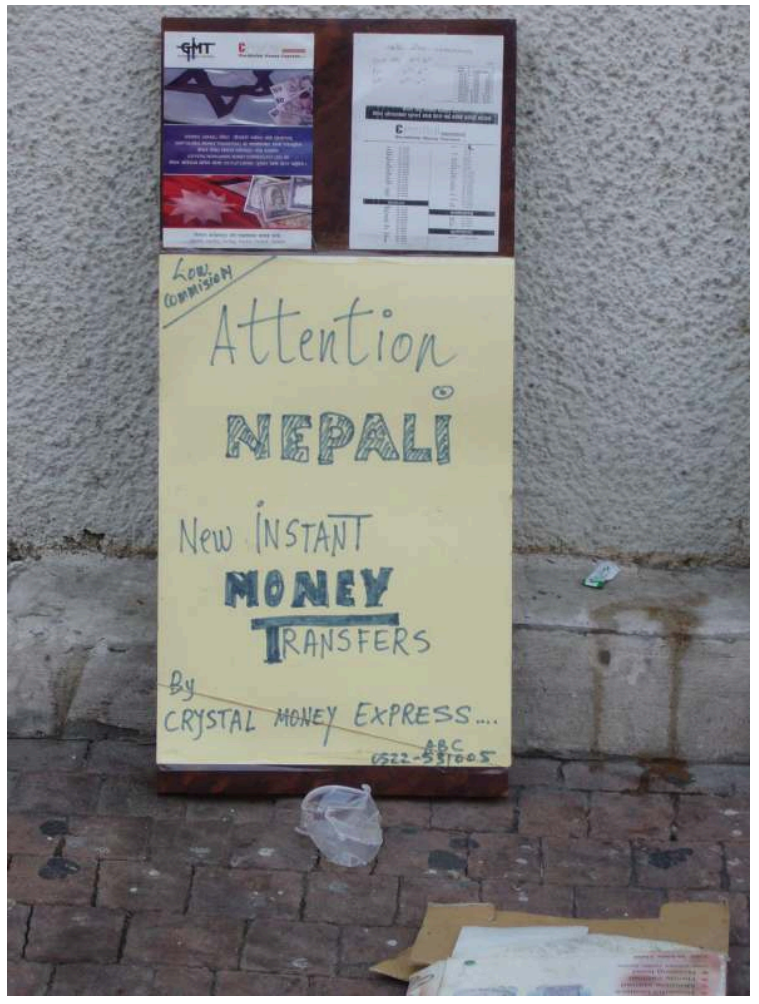

Photographer: W. Berthomière, Tel Aviv, 2008.

\section{Photographs 40: More marks}

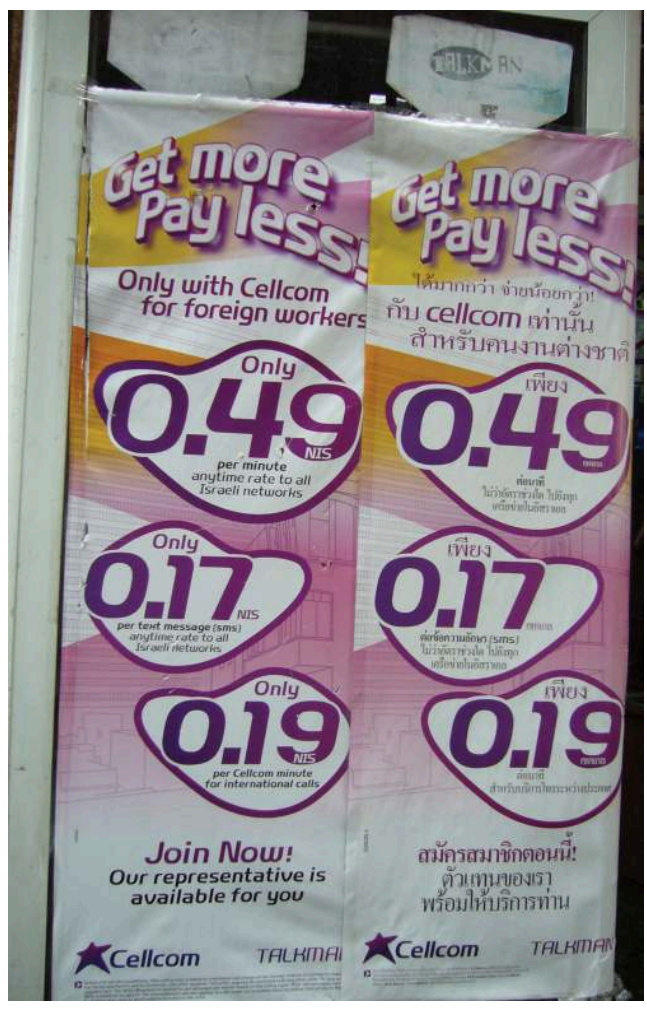

Photographer: W. Berthomière, Tel Aviv, 2008. 


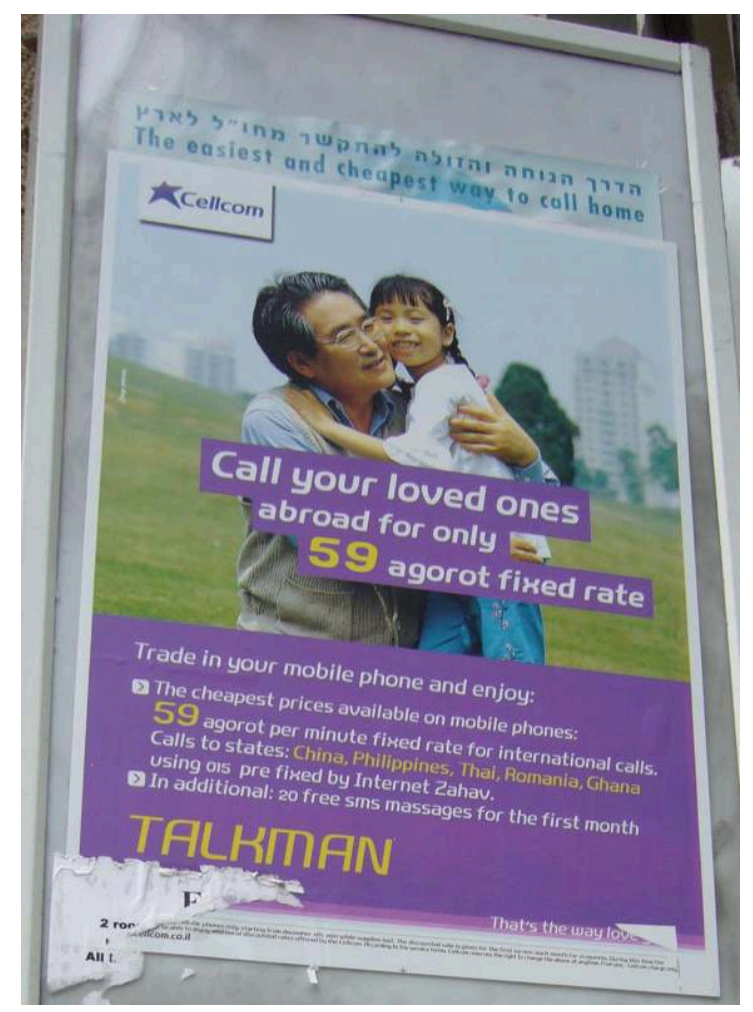

Photographer: W. Berthomière, Tel Aviv, 2008.

Nonetheless, these kinds of marks, which let us glimpse and (with more focused attention) understand a presence, do not lend themselves to the same reading:

- The first kind (photograph 39) attests to the fact that Israel is involved in what is described as the process of migratory globalization and reveals at first glance the name of a population: "the Nepali." Supposing that reading the word "attention" makes passersby slow down, reading the full content of this mark will give them a way to materialize globalization. This advertisement offering migrants a money-transfer service to their home country, placed on the very path trod by pedestrians daily, is a mark allowing passersby to imagine one nationality out of all these new migrants and to make a concrete connection to these international movements.

- The second kind, seen in photographs 40 and 41 , can lead to another interpretation of the observed elements. By making it possible to put a face on these new immigrants in Israel and evoking the actual experience of transnational families separated by migration in the texts, this mark enhances the realism of representation of the place and confirms passerby's perceptions. While not illustrated, reading the poster in photograph 40 may lead to a process of specifying the place. Reading the text under the mark "Only with Cellcom for Foreign Workers" makes it possible to establish a close connection between the neighborhood and the new employment-based immigration. Although this interpretation can be amplified by use of the adverb "only," the correlation does not presuppose the idea of territorial appropriation, because the space of the photograph may reveal the full complexity of a place whose density accrues from successive presences. 
Photographs 41 and 42 clearly illustrate the questioning that occurs when observation offers the possibility of reading marks and traces simultaneously. By focusing the camera on spotting the marks dotting pedestrians' path, I chose to isolate elements attesting to the presence of new immigrants, like these advertisements. Further broadening the field of view, this advertisment is embedded in an even denser existence. Photograph 42 reveals another reading of the situation offered up to passersby, framed by the mediation provided by the spatial proximity of the trace and the mark. Attentive observation makes it possible to spot the presence of older notices aged by pollution and the passage of time since they were current. The sensitive regard of attentive passersby allows them to see the relics of notices written in Cyrillic characters and to integrate their interpretations of their observations in the long history of the neighborhood. The location of this advertisement permits an interpretational shift offering passersby the opportunity to add a dimension of memory to their reading, seeing their observation of the mark in another light: Neve Sha'anan is a historical neighborhood of immigration where a great many immigrants settled for longer or shorter periods, including Jews arriving after 1989 from the former Soviet Union, and from Morocco before that. Today Asian laborers that have come to replace Palestinian workers are settling there, along with asylum-seekers from East Africa. With such a photographic object, Neve Sha'anan street is represented as a theatre of circulation whose linearity takes on depth in the traces left by former migrants on the walls of the newcomers they shelter today.

Photographs 41: Trace and mark, side by side

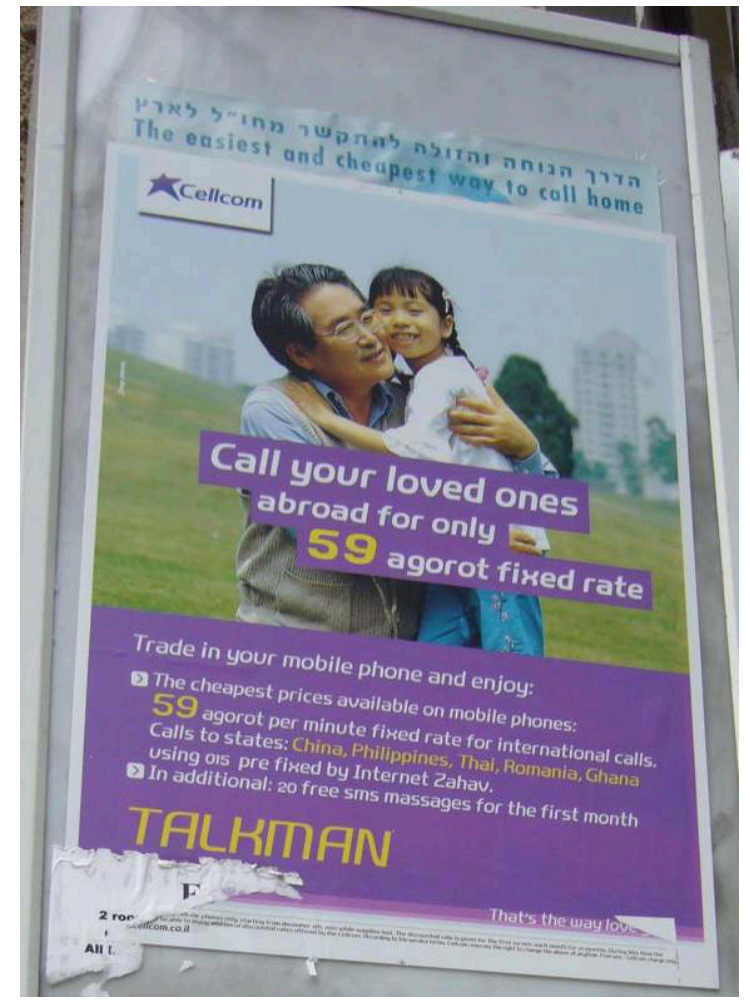

Photographer: W. Berthomière, Tel Aviv, 2008. 
Photographs 42: Trace and mark, side by side

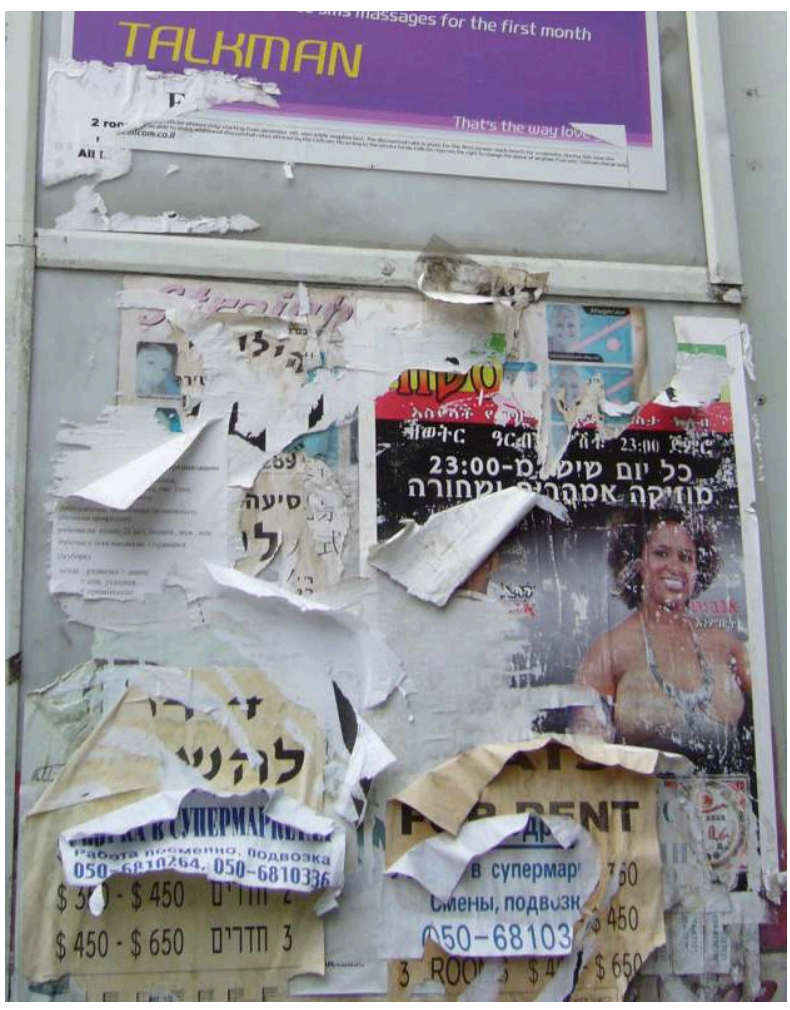

Photographer: W. Berthomière, Tel Aviv, 2008.

\section{Catching the event}

The observations and photographs made along pedestrians' path on Neve Sha'anan street made me wonder about the connections that develop between circulation and events. The street is a space of interactions where the emergence of events of various natures and intensities influences perceptions of the place, and thus how it is represented based on new descriptions of it (Berdoulay, 1997). The scale of commercial activity makes a multitude of interactions that can be captured by photography aligned with academic work making the public space a scene for appearance that can be considered "both as a form and an event" (Quéré, 1995).

73 Field photography thus allows us access to another space for exploring and identifying how passersby do or do not catch on to events along their route, and how such events help them to comprehend the social changes shaping the neighborhood and lead them to rethink how "the Foreigner" establishes himself in his everyday space by freeing himself from "a territorial logic of peopling that makes a given morphology correspond with a particular symbol system, a space and a community. The work of the passerby or spectator is always, in this regard, one of repossession and reconfiguration" (Joseph, 1995).

74 I offer photographs 43 and 44 as examples illustrating this kind of approach (Quéré, 1995). Analysis of focused interactions ${ }^{16}$ in Israeli public space has proven to be even greater food for thought because the "Israeli" street is a theater for the expression of identities that, at first glance, break with the image projected by "French" streets, where notions of public space and laïcité, the distinct version of secularism that 
predominates in France, are metonymic. Floating observation of Tel Aviv unfailingly catches public street scenes that offer a reading of Israeli society in all its dimensions, be they on the order of ordinary nationalism (Martigny, 2010) or "interplay" between individuality and pressing duty to the group. ${ }^{17}$

Such a research perspective is thus found embodied in a demonstration by followers of Falun Dafa. ${ }^{18}$ This event took place at the heart of Neve Sha'anan street at the same time as the weekly flea market that was founded by foreign workers. As these photographs show, Israeli followers of Falun Dafa took a place and chose to publicly exhibit their spirituality through ritual dance and meditation in the midst of the activities of the neighborhood's immigrant population.

Photographs 43: An event: followers of Falun Dafa on rue Neve Sha'anan

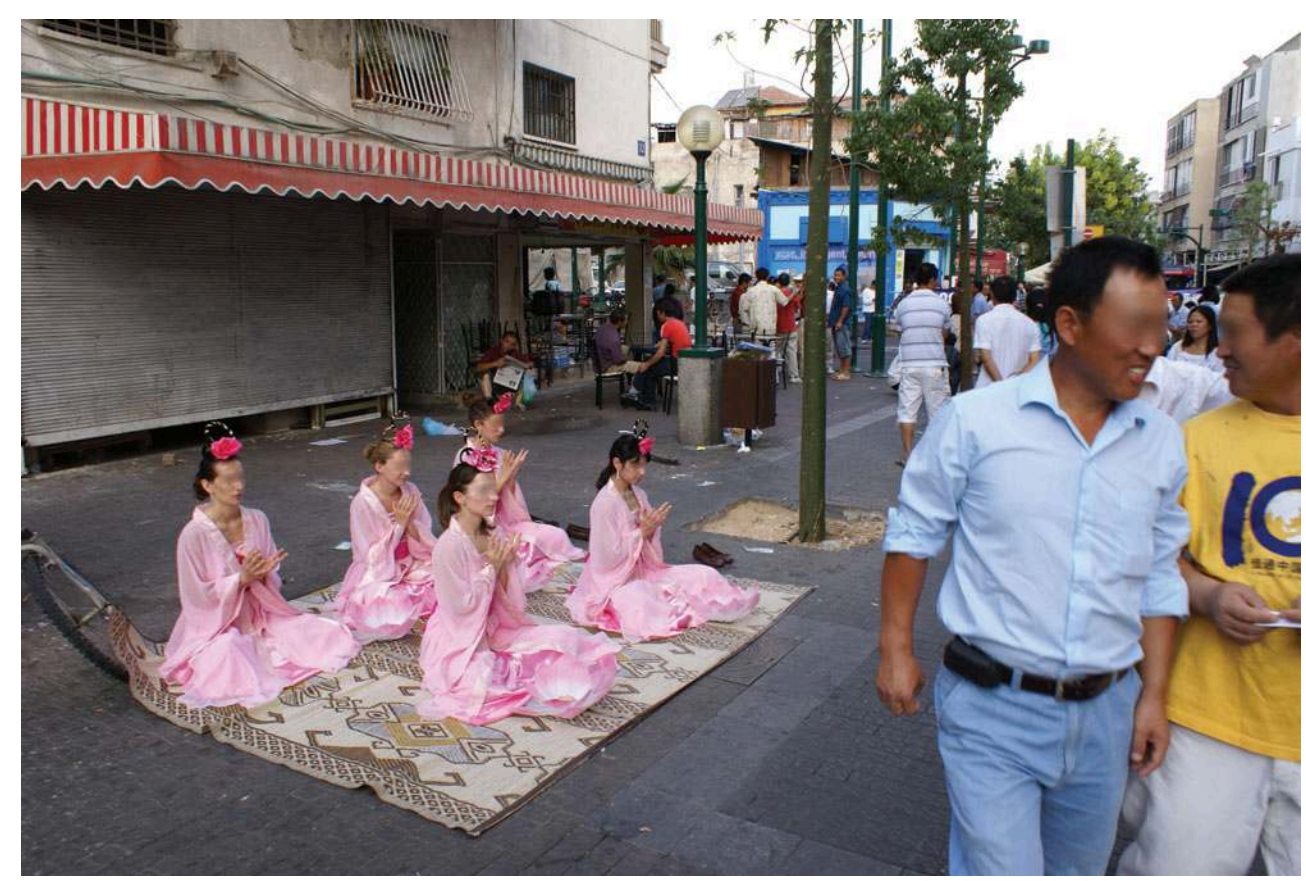

Photographer: W. Berthomière, Tel Aviv, 2007. 
Photographs 44: An event: followers of Falun Dafa on rue Neve Sha'anan

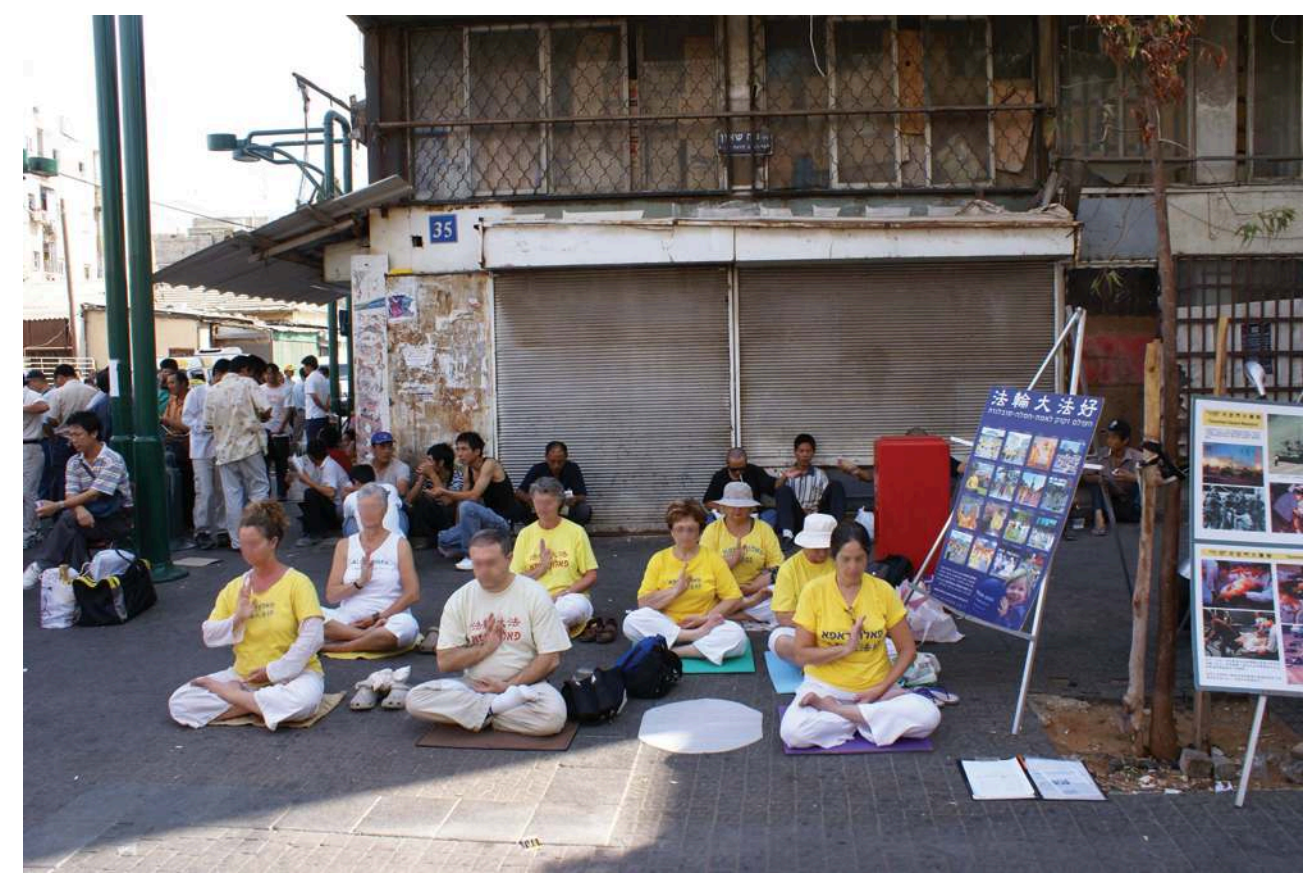

Photographer: W. Berthomière, Tel Aviv, 2007.

In a first level of reading, and to resume analysis of interactions, we can see how this event strikes people attending the market. Passersby, migrant or not, let their incomprehension or astonishment be seen. Analysis of photographs of the setting of these focused interactions highlights the kind of attention these Falun Dafa "actors" get from Asian workers, whose reactions may make practitioners into a laughing stock (photograph 43) or manifest indifference, as seen in those behind the meditating group (photograph 44).

In a second level of reading, these photographs illustrate the necessity of the repossession and reconfiguration work mentioned by Isaac Joseph. Such an experience obliges passersby to revise the representation of the space they are crossing. Passersby are no longer solely observing the present of foreigners' presence, but also an event where this world of migrants is the scene that some Israelis choose to express an "Other-identity," in this "Other-place," deciding to insert themselves into an "Asian corner society" about which they know practically nothing. The representation offered to passersby could be analyzed as an inversion of the space, in that it would become the reverse of their everyday perception: the "migratory globalization" street no longer exhibits the Stranger, but rather the Autochthone that wants to be an Other, trying to place himself at a distance from an Israeli national imaginary with very strong boundaries. And for the researcher, using photography helps us to pin down minority visibilities, their many facets revealing their true complexity over the series of pictures, not to mention their plasticity and above all fleetingness, as in these words of Virginia Woolf, which Isaac Joseph chose to introduce his book, Passant Considérable: "All these things happened in one second and last forever. The mirage of human figures rises on the horizon. They appear on the street corner." 


\section{Conclusion}

We have long known the predominance of sight over the other senses in urban settings, since it was first formulated by Simmel in 1903. Photography expresses this sense from a wide range of perspectives, creating visions, sparking visualizations, intensifying possibilities, uncovering the "unseen." The photographic approach has unquestionably flooded urban studies in general, and especially social anthropology and urban geography. The materiality and human expressivity of places make the city a privileged object of study. The aesthetics of representation concerns artists and researchers at many levels, but the medium of photography also "introduces something new and strange [...] [that] will never consent to being wholly absorbed in 'art."' (Benjamin 1999, 510).

After making the rounds of emergent work on great contemporary metropolises and their migratory components, one is struck by the diversification of photographic methods and outcomes. The intention is not the same as those of the turn of the twentieth century, to awaken public opinion blind to the miseries of working people, a group that overlapped heavily with the migrant population at the time. Today it is intended to attest to the diversity of ethnic and cultural presence in urban spaces and provide an account of the infinite variety of forms of participation in city life. Foreigners, migrants, refugees, minorities... there are many terms, certainly not synonyms, for qualifying those who, despite being distinctive for certain specific identities, have settled or rooted themselves in the city and contribute to its activity. Photography tackles what occurs in the public space and what is deliberately exhibited in visible pride of its singularity, commercial reasons included. But it also reveals more cryptic practices that reside at the site of a certain cultural intimacy (Herzfeld, 2005). Although these practices are in public view, they can only be understood if the keys for interpreting this intimacy are made explicit.

The transformation of urban photography goes much further, however, since it also influences the very role of photographic images in the city. The studies presented in this collection reveal photographs' power to transform how a neighborhood is viewed, their capacity to metamorphose city residents' perceptions of the other and its differences, and their power to accommodate even the most disconcerting of particularisms. We realize that the photographic image is one of the most magical tools for urban projects, public policy, artistic expression, and social science research. The image spurs the real to go further, photographers using them to consciously or unconsciously point reality in the desired direction. Today this capacity for transformation is implemented daily to enchant, give a good impression, educate, or preserve despite it all. In the specific relationship that interests us here, that of metropolises with their migrant populations, photography is confirmed as much in its function for the advancement of knowledge as in its power to transform perceptions of alterity. 


\section{BIBLIOGRAPHY}

\section{Anne Raulin}

Allali Jean-Pierre, Goldmann Annie, Sebag Paul, Sitbon Claude, Taïeb Jacques, Tapia Claude et Valensi Lucette (Dirs.) (1997 [1989]) Les Juifs de Tunisie, Paris, Scribe, 160 p.

Appaduraï Arjun (2015 [1996]) Après le colonialisme. Les conséquences culturelles de la globalisation [traduit par Françoise Bouillot], Paris, Payot, 336 p.

Audebert Cédric (2006a) L'insertion socio-spatiale des Haïtiens à Miami, Paris, L'Harmattan, 297 p.

Audebert Cédric (2006b) Les communautés antillaises aux États-Unis : entre métropolisation et logiques réticulaires transnationales, Espace populations sociétés, 1, pp. 137-149.

Ballif Florine, Cuny Cécile, Färber Alexa et Jarrigeon Anne (Éds.) (2017) Penser l'urbain par l'image. Collaborations entre chercheurs et producteurs d'images dans la recherche urbaine, [en ligne]. URL : https://cecilecuny.files.wordpress.com/2012/08/presentation-seminairecollaborations-2014-2015-fd.pdf

Barou Jacques (2010) Immigrés africains en France et au Royaume-Uni, Hommes \& Migrations, 1286-1287 (4), pp. 110-123.

Barth Fredrik (1995 [1969]) Les groupes ethniques et leurs frontières, in Philippe Poutignat et Jocelyne Streiff-Fenart, Théories de l'ethnicité, Paris, Presses universitaires de France, pp. 203-249. Barthes Roland (1980) La chambre claire. Note sur la photographie, Paris, Gallimard-Le Seuil, 200 p. Becker Howard S. (2007) Les photographies disent-elles la vérité ?, Ethnologie française, 37 (1), pp. 33-42.

Becker Howard S. (2002) Visual Evidence: A Seventh Man, the Specified Generalization, and the Work of the Reader, Visual Studies, 17 (1), pp. 3-11.

Becker Howard S. (Ed.) (1981) Exploring Society Photographically, Evanston, Mary and Leigh Block Gallery and Northwestern University, 96 p.

Benjamin Walter [2015 (1931)] Petite Histoire de la photographie [traduit par Lionel Duvoy], Paris, Allia, $48 \mathrm{p}$.

Berdoulay Vincent (1997) Le lieu et l'espace public, Cahiers de Géographie du Québec, 41 (114), pp. 301-309.

Berger John and Mohr Jean [1982 (1975)] A Seventh Man. Migrant Workers in Europe, London, Writers and Readers Publishing Cooperative, $248 \mathrm{p}$.

Billig Michael (1995) Banal nationalism, Londres, Sage, 208 p.

Certeau Michel (de) (1990) L'invention du quotidien, Paris, Gallimard, 347 p.

Collier John Jr. (1967) Visual Anthropology: Photography as a Research Method, New York Holt, Rinehart and Winston, $266 \mathrm{p}$.

Conord Sylvaine (2010) Le pèlerinage Lag ba-Omer à Djerba (Tunisie). Une forme de migration touristique, in Katia Boissevain Éd., Socio-anthropologie de l'image au Maghreb, Nouveaux usages touristiques de la culture religieuse, Paris, L'Harmattan, pp. 105-116.

Conord Sylvaine (Dir.) (2007a) Arrêts sur images. Photographie et anthropologie, Ethnologie française, 37 (1), $183 \mathrm{p}$. 
Conord Sylvaine (2007b) Usages et fonctions de la photographie, Ethnologie française, 37 (1), pp.

11-22.

Conord Sylvaine (2002) Le choix de l'image en anthropologie : qu'est-ce qu'une «bonne » photographie ?, Ethnographiques.org, [en ligne] consulté le 08/10/2015. URL : http:// www.ethnographiques.org/2002/conord.html

Conord Sylvaine and Cuny Cécile (Eds.) (2014) Towards a "visual turn" in urban studies? Photographic approaches, Visual Ethnography, 3 (1), pp. 1-6, [online]. URL: http:// www.vejournal.org/index.php/vejournal/article/view/49/58

Cordié Lévy Marie (2011) The Radical Camera, New York's Photo League, 1936-1951, Transatlantica, 2, (en ligne), consulté le 21 août 2016. URL : http://transatlantica.revues.org/5609 Cuny Cécile, Färber Alexa und Hägele Ulrich (Eds.) (2014) Fotografie und städtischer Wandel, Fotogeschichte, 131 (34).

Diminescu Dana (2005) Le migrant connecté. Pour une manifestation épistémologique, Migrations Société, 17 (102), pp. 275-292.

Dubois Philippe (1990) L'acte photographique et autres essais, Paris, Nathan, 309 p.

Ebilitigué Ines (2014) Réseaux virtuels et commerces ethniques : une dynamique entre l'espace des flux et l'espace urbain, Thèse en sociologie (sous la dir. d'Anne Raulin), Université Paris Ouest - Nanterre la Défense, 396 p.

Färber Alexa and Gdaniec Cordula (2004) Shopping Malls and Shishas. Urban Space and Material Culture as Approaches to Transformation in Berlin and Moscow, Ethnologia Europeae. Journal of European Ethnology, 34 (2), pp. 113-128.

Garrigues Emmanuel (1991) Ethno-photographie du quartier sud de la Goutte d'or, XVIIIe arrondissement de Paris, L'ethnographie, 87 (109), pp. 119-127.

Goldstein Judith L. (2008) The flaneur, the street photographer and ethnographic practice, Contemporary Jewry, 28 (1), pp. 121-124.

Halbwachs Maurice (1997 [1950]) La mémoire collective, Paris, Albin Michel, 105 p.

Harper Douglas (2012) Visual Sociology, Londres, Routledge, 312 p.

Hassoun Jean-Pierre (1992) Pratiques religieuses et entreprises chinoises à Paris. Un paysage favorable, Revue Européenne des Migrations Internationales, 8 (3), pp. 139-154.

Herzfeld Michael (2005) Cultural Intimacy. Social Poetics in the Nation-State, New York, Routledge, $296 \mathrm{p}$.

Hine Lewis W. (1977 [1932]) Men at Work, New York, Dover Publications, 63 p.

Joseph Isaac (2006) Les compétences de rassemblement. Une ethnographie des lieux publics, Enquête, 4, pp. 107-122.

Joseph Isaac (1998) Erving Goffman et la microsociologie, Paris, Presses Universitaires de France, $126 \mathrm{p}$.

Joseph Isaac (1995) Reprendre la rue, in Isaac Joseph, Prendre place espace public et culture dramatique, Paris, Recherches Plan urbain, pp. 11-35.

Joseph Isaac (1984) Le passant considérable. Essai sur la dispersion de l'espace public, Paris, Librairie des Méridiens, $146 \mathrm{p}$. 
Kozloff Max (2002) New York: Capital of Photography, New York, The Jewish Museum/New Haven and Yale University Press, 208 p.

Laplantine François (2005) Le social et le sensible. Introduction à une anthropologie modale, Paris, Téraèdre, $220 \mathrm{p}$.

Luca Nathalie (2012) Y croire et en rêver. Réussir dans le marketing relationnel de multiniveaux, Paris, L'Harmattan, $224 \mathrm{p}$.

Ma Mung Guillaume (2016) L'appropriation des lieux du commerce ethnique à Paris et à Londres. Regards croisés sur Château Rouge et Brixton, Thèse en géographie, Université Paris Ouest - Nanterre La Défense, $250 \mathrm{p}$.

Ma Mung Emmanuel (2006) Négociations identitaires marchandes, Revue Européenne des Migrations Internationales, 22 (2), pp. 83-93.

Maresca Sylvain (1996) La photographie: Un miroir des sciences sociales, Paris, L'Harmattan, 267 p.

Maresca Sylvain et Meyer Michaël (2013) Précis de photographie à l'usage des sociologues, Rennes, Presses universitaires de Rennes, 109 p.

Martigny Vincent (2010) Penser le nationalisme ordinaire, Raisons politiques, 1 (37), pp. 5-15.

Mavrommatis George (2011) Stories from Brixton: Gentrification and Different Differences, Sociological Research Online, 16 (2), p. 12.

Mead Margaret and Bateson Gregory (1942) Balinese character. A photographic analysis, New York, Academy of Sciences, $277 \mathrm{p}$.

Miller Daniel (1987) Material Culture and Mass Consumption, Oxford, Basil Blackwell, $232 \mathrm{p}$.

Moles Abraham (1990) Les sciences de l'imprécis, Paris, Le Seuil, 360 p.

Molina-Marmol Maïté (2009) De l'usage de la photographie dans une enquête ethno-sociologique sur la mémoire de l'exil et de l'immigration espagnols en Belgique, Conférence présentée lors du colloque « La lettre et l'image. Enquêtes interculturelles sur les territoires du visible », [en ligne]. URL : http:// web.philo.ulg.ac.be/culturessensibles/wp-content/uploads/sites/34/pdf/Mait\%C3\%A9-1.pdf Moore Deborah Dash (2008) The Marshall Sklare Award: On City Streets (Paper presented at the annual Association for Jewish Studies conference, 2006), Contemporary Jewry, 28 (1), pp. 84-108.

Musterd Sako, Ostendorf Wim and Breebaart Matthijs (1998) Multi-ethnic metropolis: patterns and policies, Netherlands, Dordrecht/Boston, Kluwer Academic Publishers, 208 p.

Nuvolati Giampaolo (2009) Le flâneur dans l'espace urbain, Géographie et cultures, 70, [en ligne] consulté le 02/08/2016. URL : http://gc.revues.org/2167

Peirce Charles S. (1978) Écrits sur le signe, rassemblés, traduits et commentés par Gérard Deledalle, Paris, Le Seuil, $263 \mathrm{p}$.

Péquignot Bruno (2008) Recherches sociologiques sur l'image, Paris, L’Harmattan, 258 p.

Pétonnet Colette (1982) L'Observation flottante. L'exemple d'un cimetière parisien, L'Homme, 22 (4), pp. 37-47.

Pezeril Charlotte (2008) Place et intérêt de la photographie dans une étude anthropologique sur l'islam au Sénégal, Ethnographiques.org, 16, [en ligne] consulté le 07/09/2015. URL : http:// www.ethnographiques.org/2008/Pezeril.html

Piette Albert (2007) Fondements épistémologiques de la photographie, Ethnologie française, 37 (1), pp. 23-28. 
Piette Albert (1992) La photographie comme mode de connaissance anthropologique, Terrain, 18, pp. 129-136.

Quéré Louis (1995) L'espace public comme forme et comme événement, in Joseph Isaac, Prendre place espace public et culture dramatique, Paris, Recherches Plan urbain, pp. 93-110.

Raulin Anne (2000) L'ethnique est quotidien. Diasporas, marchés et cultures métropolitaines, Paris, L'Harmattan, $229 \mathrm{p}$.

Riis Jacob A. (2010 [1890]), How the Other Half Lives: Studies among the Tenements of New York, Cambridge, Belknap Press of Harvard University, 368 p.

Ripoll Fabrice et Veschambre Vincent (2004) Appropriation, ESO - Travaux et Documents, 21, pp. 9-12.

Ripoll Fabrice (2006) Réflexions sur les rapports entre marquage et appropriation de l'espace, in Thierry Bulot et Vincent Veschambre Dirs., Mots, traces et marques. Dimensions spatiale et linguistique de la mémoire urbaine, Paris, L'Harmattan, pp. 15-36

Römhild Regina (2007) Fremdzuschreibungen-Selbstpositionierungen. Die Praxis der Ethnisierung im Alltag der Einwanderungsgesellschaft, in Brigitta Schmidt-Lauber Hrsg., Ethnizität und Migration. Einführung in Wissenschaft und Arbeitsfelder, Berlin, Reimer, pp. 157-178.

Rosenblum Walter, Rosenblum Naomi and Trachtenberg Allen (1997) America \& Lewis Hine, Photographs 1904-1940, New York, Aperture Books, 142 p.

Sassen Saskia (1997) Ethnicity and Space in the Global City: A New Frontier?, in Manuel Delgado Ruíz Ed., Ciutat i immigració: Debat de Barcelona (II), Barcelona, Centre de Cultura Contemporània de Barcelona (Urbanitats II), [online]. URL: http://www.publicspace.org/es/texto-biblioteca/eng/ a009-ethnicity-and-space-in-the-global-city-a-new-frontier

Sayad Abdelmalek (1985) Du message oral au message sur cassette, la communication avec l'absent, Actes de la recherche en sciences sociales, 59, pp. 61-72.

Simon Gildas (1993) Immigrant entrepreneurs in France, in Ivan Light and Parminder Bhachu Dirs., Immigration and entrepreneurship: Culture, capital, and ethnic networks, New Brunswick, Transaction Publishers, pp. 125-139.

Soulages François (2005) Esthétique de la photographie, Paris, Armand Colin, 336 p.

Steiner Anne et Conord Sylvaine (2010) Belleville cafés, Paris, L'échappée, 119 p.

Tapia Claude et Lasry Jean-Claude (Dirs.) (1989) Les Juifs du Maghreb : Diasporas contemporaines, Paris, L'Harmattan, 480 p.

Tapia Claude et Simon Patrick (1998) Le Belleville des Juifs tunisiens, Paris, Autrement, 189 p.

Terrenoire Jean-Paul (1985) Images et sciences sociales : l'objet et l'outil, Paris, Revue française de sociologie, 26 (3) pp. 509-527.

Thibaud Jean-Paul (2015) En quête d'ambiances. Éprouver la ville en passant, Genève, MétisPresses, $328 \mathrm{p}$.

Thibaud Jean-Paul et Tixier Nicolas (1998) L'ordinaire du regard, in Le Cabinet d'Amateur, Actes du colloque Perec et l'image, Toulouse, Presses Universitaires du Mirail, 7-8, pp. 51-67.

Tocheva Detelina (2015) Kurban: shifting economy and transformations of a ritual in upland Bulgaria, in Stephen Gudeman and Chris Hann Dirs., Economy and Ritual: Six Studies of Postsocialist Transformations, New York, Berghahn Books, pp. 107-136. 
Topalov Christian (1997) Maurice Halbwachs, photographe des taudis parisiens (1908), Genèses, 28, pp. 128-145.

Veschambre Vincent (2008) Traces et mémoires urbaines enjeux sociaux de la patrimonialisation et de la démolition, Rennes, Presses universitaires de Rennes, 315 p.

Wang Jin (2015) Où sont passés les ancêtres? Morts et vivants dans une famille chinoise aujourd'hui ?, L'Homme, 214, pp. 75-106.

Warnier Jean-Pierre (Dir.) (1994) Le paradoxe de la marchandise authentique, Paris, L'Harmattan, $190 \mathrm{p}$.

Weber Max (1964 [1905]) L'éthique protestante et l'esprit du capitalisme, Paris, Plon, 285 p.

\section{NOTES}

1. Sol Libsohn's photographs of Hester Street (1938) and the Harlem Document, coordinated by Aaron Siskind, both came out of the New York Photo League.

2. Sid Grossman was a founder of the New York Photo League. For more information, see Cordié Lévy (2011).

3. A selection of the writings of semiologist Charles Sanders Peirce (1838-1914) was translated into French and published in 1978, under the title Écrits sur le signe (edited, translated and commented by Gérard Deledalle).

4. This research began in 1995 and spanned five years. It was carried out within the framework of a doctoral thesis conducted under the supervision of Carmen Bernand and defended in 2001 at Université Paris Ouest - Nanterre La Défense.

5. "The Jews spoke an Arabic dialect, related to all the so-called sedentary dialects, as opposed to the more recent nomadic dialects introduced into the Maghreb by the Hilal Bedouins. The language spoken by Jews is therefore only a particular variation of the language spoken by city dwellers or villagers. As such, it espouses the characteristics and especially the archaisms of this language. It remains that some negligible subtleties contributed to characterising a Jewish dialect. These subtleties concern phonology, accent and lexicon, the morphological differences with Muslim dialects being almost nil. [...] Peculiarities of accent are also typical of Jewish speech. It is a sing-song accent and is more marked in Tunis than elsewhere; among the workingclass of Tunis, especially among women, one finds a caricatural and sometimes shocking accent" explain Tapia and Lasry (1989: 51-52).

6. These clients of the Café La Vielleuse were between sixty-five and eighty years old at the time of the study.

7. The pilgrimage of Lag ba-Omer (in Hebrew Lag means thirty-three) corresponds to the period called Omer, beginning on the second day of Pesach (the day of the first sheaf of barley is offered to God) and ending on the thirty-third day of Omer according to Tunisian Jews. It takes place once a year.

8. In 1995, I was invited to follow Gisèle, one of the clients of the Café La Vielleuse, from Belleville to Israel to participate in the Lag ba-Omer pilgrimage

9. In 1996, Gisèle asked me once again to accompany her to Tunisia to the island of Djerba where the famous synagogue of El Ghriba is located.

10. During the pilgrimage, a day trip is organised to Tunis by the travel agency.

11. My various experiences in the field working with the homeless, the committee for the defence of the homeless, in the districts of La Courneuve or the Goutte d'Or, and currently my work on the ways in which residents represent their neighbourhood in Lisbon, Vienna and Brussels, have also fuelled this reflection. 
12. A classic Chinese historical novel on the late Han dynasty and the Three Kingdoms period (the third century), written in the fourteenth century.

13. This text is based on fieldwork consisting of regular observation of this site since 1999 and immersion during the 2010-2012 period.

14. The sensory approach as used here can be defined in the terms of Laplantine (2005), "to signify attention, listening, an attitude of hospitality [...] the life of sensations." He mentions the empirical dimension of this perspective that includes "an obviousness of the sensory, or more precisely an impression of obviousness, which is that of a presence to the world, oneself, and others."

15. Expression from Joseph (2006).

16. Erving Goffman defines them as "occasions." The transformation of "the matter of interactions [...] seeks the attention of interactants. It then go from a non-focused interaction (a simple set of circumstances) to a focused interaction, an occasion" (Joseph, 1998).

17. The expression "banal nationalism" could also have been used, in reference to Billig (1995). Martigny (2010) suggests using "the idea of 'ordinary' nationalism [...], more neutral than the term 'banal', which has a pejorative connotation in French."

18. According to the website Falundafa.org, "Falun Dafa (also called Falun Gong, or simply Dafa) is a high-level method of 'cultivation' and practice guided by characteristics of the Universe Authenticity, Benevolence, Patience. 'Cultivation' is the process of continual self-correction and assimilation to these universal principles. The practice consists of five exercises using gentle movement and meditation. 'Cultivation' is the cornerstone of Falun Dafa, supplemented by practicing the exercises. With time, the principles of Dafa reveal the deep truths of the Universe. By following these principles, practitioners may attain higher realms of thought, awakening to the profound meaning of existence and finding the path for returning to their origins and authenticity."

\section{ABSTRACTS}

Since photography was invented, its techniques and uses have kept evolving throughout the 19th, 20th and 21stcenturies. The Thirties marked a turning point when American anthropologists considered photographic images as a legitimate instrument for ethnographic research. Renewed historical conditions, migration currents and the recent digital revolutions radically changed the connection between this media and the social sciences. Considering the last thirty years of research on migration and its visibility in contemporary metropolises, seven researchers contribute here to give an account of how photographic documentation moved from "social photography" to "participative photography" - nevertheless keeping ethnographic purposes in mind. In this process, migrants may have become active participants in producing images, which enhance the city, more precisely their own neighbourhood, and in staging local otherness. As for the photographer-researcher, s/he may choose between a variety of positions, working as an active witness of their individual or collective history, as an ethnographer revealing cultural particularisms, an artist catalyst of social perceptions, a flâneur drifting along floating observations... so following the democratization of the use of images which allows a permanent invention of means of expression. 
Depuis son invention, la photographie et ses usages n'ont cessé d'évoluer du XIXe au XXIe siècle. Les années 1930 ont marqué un tournant quand des anthropologues étatsuniens ont considéré l'image photographique comme un instrument de recherche à part entière. Les transformations des conditions historiques, du sens des migrations, puis les récentes révolutions numériques ont radicalement changé le rapport des sciences sociales à ce médium. Considérant les trente dernières années de recherche sur les migrations et leur visibilité dans les métropoles contemporaines, sept contributions viennent ici décrire la façon dont le travail photographique s'est émancipé de la "photographie sociale " pour aboutir à la «photographie participative »sans pour autant abandonner le propos ethnographique. Dans ce mouvement, les habitants ont $\mathrm{pu}$ devenir acteurs dans la captation d'images qui valorisent la ville et leur quartier d'immigration et participer à certaines formes de mise en scène de l'altérité locale. Quant au chercheur/e-photographe, il/elle a désormais à sa disposition diverses postures, comme témoin actif de la biographie individuelle ou collective de ces populations, révélateur de particularismes culturels, artiste catalyseur de perceptions sociales, flâneur dérivant au gré de son observation flottante... suivant la démocratisation du rapport à l'image qui ne cesse de susciter de nouvelles modalités d'expression.

La fotografía y sus usos han estado evolucionando constantemente desde que se inventó ésta en el siglo XIX hasta el siglo XXI. Los años 1930 han marcado un viraje cuando antropólogos estadounidenses empezaron a considerar la imagen fotográfica como instrumento de investigación de pleno derecho. Las condiciones históricas, el sentido de las migraciones, y luego las recientes revoluciones numéricas han cambiado radicalmente la relación entre las ciencias sociales y este médium. Tomando en cuenta los últimos treinta años de investigación sobre las migraciones y su visibilidad en las metrópolis, siete contribuciones describen aquí la manera en que la documentación fotográfica se ha emancipado de la «fotografía social» para llegar a la «fotografía participativa» - sin abandonar por ello el propósito etnográfico. Dentro de esta dinámica, los migrantes han podido convertirse en actores de la captación de imágenes que valorizan la ciudad y su barrio de vivienda, participando en ciertas formas de puesta en escena de la alteridad local. En cuanto al investigador-fotógrafo, él oscila en adelante entre diversas posturas: testigo activo de la biografía individual o colectiva de estas poblaciones, revelador de particularismos culturales, artista catalizador de percepciones sociales, azotacalles derivando a merced de su observación flotante... siguiendo la democratización de la relación con la imagen que sin cesar suscita nuevas modalidades de expresión.

INDEX

Palabras claves: migrantes, metrópolis, visibilidad, etnografía, fotografía (social, participativa) Keywords: migrants, global cities, visibility, ethnography, photography (social, participative) Mots-clés: migrants, métropoles, visibilité, ethnographie, photographie (sociale, participative)

\section{AUTHORS}

\section{ANNE RAULIN}

Professeure d'anthropologie urbaine, Université Paris Nanterre, Sophiapol/IIAC-LAUM, 200 avenue de la République, 92001 Nanterre cedex ; araulin@parisnanterre.fr 


\section{SYLVAINE CONORD}

Maîtresse de conférences en sociologie, Photographe, Université Paris Nanterre, Mosaïques/ LAVUE, 200 avenue de la République, 92001 Nanterre cedex ; sylvaine.conord@parisnanterre.fr

\section{WILLIAM BERTHOMIÈRE}

Géographe, Directeur de recherche au CNRS, Université de Bordeaux Montaigne, PASSAGES, Maison des Suds, 12 esplanade des Antilles, 33607 Pessac cedex ; william.berthomiere@cnrs.fr

\section{INES EBILITIGUÉ}

Attachée temporaire d'enseignement et de recherche, Université Paris Nanterre, 200 avenue de la République, 92001 Nanterre cedex ; inesebilitigue@gmail.com

\section{ALEXA FÄRBER}

Professeure d'anthropologie urbaine et d'ethnographie, HafenCity Université de Hambourg, Überseeallee 16, 20457 Hambourg, Allemagne ; alexa.faerber@hcu-hamburg.de 